\title{
WHAT MAKES RETIREES HAPPIER: A GRADUAL OR 'COLD TURKEY' RETIREMENT?
}

\author{
Esteban Calvo, Kelly Haverstick, and Steven A. Sass*
}

CRR WP 2007-18

Released: October 2007

Draft Submitted: October 2007

\author{
Center for Retirement Research at Boston College \\ Hovey House \\ 140 Commonwealth Avenue \\ Chestnut Hill, MA 02467
}

Tel: 617-552-1762 Fax: 617-552-0191

http://www.bc.edu/crr

* Esteban Calvo is a graduate research assistant at the Center for Retirement Research at Boston College (CRR). Kelly Haverstick is a research economist at the CRR. Steven A. Sass is the Associate Director for Research at the CRR. The research reported herein was performed pursuant to a grant from the U.S. Social Security Administration (SSA) funded as part of the Retirement Research Consortium. The opinions and conclusions expressed are solely those of the authors and should not be construed as representing the opinions or policy of SSA, any agency of the Federal Government, or Boston College. Please send any inquiries to Esteban Calvo at estebancalvo@gmail.com. The authors would like to thank Paula Errázuriz, Shari Grove, Natasha Sarkisian, Sarah Mack, Tay McNamara, Mauricio Soto, Alicia H. Munnell, Bob Triest, Anthony Webb, John B. Williamson, and Estelle James for their comments and other forms of help in connection to this paper. However, the authors should be held responsible for any errors or inaccuracies that remain in this article.

(C) 2007, by Esteban Calvo, Kelly Haverstick, and Steven A. Sass. All rights reserved. Short sections of text, not to exceed two paragraphs, may be quoted without explicit permission provided that full credit, including $\odot$ notice, is given to the source. 


\title{
About the Center for Retirement Research
}

The Center for Retirement Research at Boston College, part of a consortium that includes parallel centers at the University of Michigan and the National Bureau of Economic Research, was established in 1998 through a grant from the Social Security Administration. The Center's mission is to produce first-class research and forge a strong link between the academic community and decision makers in the public and private sectors around an issue of critical importance to the nation's future. To achieve this mission, the Center sponsors a wide variety of research projects, transmits new findings to a broad audience, trains new scholars, and broadens access to valuable data sources.

\author{
Center for Retirement Research at Boston College \\ Hovey House \\ 140 Commonwealth Avenue \\ Chestnut Hill, MA 02467 \\ phone: 617-552-1762 fax: 617-552-0191 \\ e-mail: crr@bc.edu \\ www.bc.edu/crr
}

\author{
Affiliated Institutions: \\ American Enterprise Institute \\ The Brookings Institution \\ Center for Strategic and International Studies \\ Massachusetts Institute of Technology \\ Syracuse University \\ Urban Institute
}




\begin{abstract}
This study explores the factors that affect an individual's happiness while transitioning into retirement. Recent studies highlight gradual retirement as an attractive option to older workers as they approach full retirement. However, it is not clear whether phasing or cold turkey makes for a happier retirement. Using longitudinal data from the Health and Retirement Study, this study explores what shapes the change in happiness between the last wave of full employment and the first wave of full retirement. Results suggest that what really matters is not the type of transition (gradual retirement or cold turkey), but whether people perceive the transition as chosen or forced.
\end{abstract}




\section{Introduction}

Workers approaching retirement often say they want to retire gradually, rather than going straight from full-time employment to complete retirement. Some surveys report that more than half of all older workers prefer to exit the labor force this way. ${ }^{1}$ This is understandable. These workers have spent thirty or more years in the labor force, and retirement represents a sharp social, psychological, and economic break with life as they know it. So it is not surprising that workers prefer to negotiate the transition in stages. A smooth transition allows older workers to continue daily activities similar to those performed in middle-age. In this sense, gradual retirement appears to be helpful in maintaining meaning and a sense of purpose in life, as well as adapting to aging. ${ }^{2}$ Gradual retirement also could enhance opportunities to remain active and socially engaged. Evidence suggests that remaining active and socially engaged has a strong positive impact on health and well-being in retirement. ${ }^{3}$

Many policymakers also view gradual retirement favorably, as a way workers can extend their careers and thereby improve retirement income security. ${ }^{4}$ One out of three workers age 55 and over say they would stay in the labor force longer if they could cut back their hours. ${ }^{5}$ And two out of three workers age 50 to 70 say they plan to work in “retirement." ${ }^{6}$ To accommodate worker preferences, to facilitate more successful transitions into retirement, and to improve retirement income security, expanding

\footnotetext{
${ }^{1}$ See Hutchens (2007) and US General Accounting Office (2001).

${ }^{2}$ Atchley (1999); Rowe and Kahn (1998).

${ }^{3}$ Brummett et al. (2001); Cohen (2004); Erickson, Erikson and Kivnick (1986); Everard, Lach, Fisher and Baum (2000); Siegrist, Von dem Knesebeck and Pollack (2004).

${ }^{4}$ It is uncertain whether this does in fact happen in general. While some individuals may work longer than they would otherwise with gradual retirement, others end their full-time employment earlier when given the option to decrease hours. See Gustman and Steinmeier (2007).

${ }^{5}$ Watson Wyatt (2004).

${ }^{6}$ Brown (2003).
} 
opportunities for gradual or "phased" retirement has gained a prominent place on the policy agenda. ${ }^{7}$

It is not clear, however, that retirees are indeed better-off if they retire gradually as opposed to cold turkey. Workers who want to retire gradually are not basing their preference on their own personal experience. They have not retired both ways-coldturkey and in stages — and conclude that that they are happier in retirement after a gradual transition. ${ }^{8}$

Our study seeks to learn whether individuals are indeed better off if their transition out of the labor force is gradual as opposed to abrupt. We use happiness as the yardstick for evaluating the work-retirement transition. Happiness has an important advantage over other yardsticks, as it measures realized quality of life. Other criteria, such as income, wealth, social status, or health, measure potential quality of life. ${ }^{9}$ Our study thus asks whether retirees who exited the labor force gradually are "happier" than those who left cold-turkey. By happiness we mean the individual's general experience of different kind of feelings. Some feelings we experience are pleasurable, such as enjoyment of life. Others, such as sadness, are unpleasant. Our study asks whether the type of transition from work to retirement affects the degree to which the various feelings a person experiences are generally pleasant or enjoyable. ${ }^{10}$

This paper is organized as follows. Section I reviews the literature on the pros and cons of gradual versus abrupt transitions to retirement and on factors that influence happiness in retirement. Section II describes the data, including the indicators used to measure happiness and gradual as opposed to abrupt retirement, the independent variables included in the model, and the study methodology. Section III reports summary statistics and regression results. Section IV discusses the results and concludes.

\footnotetext{
${ }^{7}$ The term "phased retirement" is sometimes limited to full-time workers reducing their hours in their current job. For example, see Hutchens and Papps (2005) and Hutchens (2007). Our focus here is the broader concept of retirement in stages, not necessarily with the same employer.

${ }^{8}$ Daniel Gilbert (2007) explains why individuals typically misestimate their future happiness.

${ }^{9}$ Di Tella and MacCulloch (2006); Frey and Stutzer (2002); Kahneman and Krueger (2006); Veenhoven (2000; 2002).
} 


\section{Literature Review}

\section{A Gradual versus an Abrupt Transition}

The psychological literature generally supports a gradual work to retirement transition. Retirement is a major life event, with strong psycho-social implications, and a gradual transition allows older individuals to continue daily activities similar to those performed in middle-age. ${ }^{11}$ This helps maintain a sense of identity and purpose in life, and keeps older individuals active and socially engaged. Studies have shown that these effects have a positive impact on health, well-being, and adapting to aging. ${ }^{12}$

On the other hand, psychologists also find that people are quite resilient. Happiness is very stable across the life span, with large shocks often having but a shortterm effect on our mood and sense of well-being. Thus these authors argue that individuals have a normal baseline level of well-being that varies only moderately in response to current events. ${ }^{13}$ This perspective would suggest that the type of transition would not have a meaningful effect on happiness in retirement.

\section{Factors That Influence Happiness}

Researchers have found that most retirees are happy in retirement. But they also find that the degree of satisfaction fluctuates substantially and is associated with various characteristics. ${ }^{14}$ A few studies also have attempted to measure the effect of continued work on happiness in retirement, which is similar to our concern for the effect of gradual

\footnotetext{
${ }^{10}$ There are many ways to define happiness, and Appendix A provides a brief review of the various conceptions.

${ }^{11}$ Fouquereau, Fernández, Fonseca, Paul and Virpi (2005).

${ }^{12}$ For health, see Brummett et al. (2001); Everard et al. (2000); Siegrist, Von dem Knesebeck and Pollack (2004). For well-being, see Cohen (2004); Erickson, Erikson and Kivnick (1986). For adapting to aging, see Atchley (1999); Rowe and Kahn (1998).

${ }^{13}$ For example, Costa, McCrae and Norris (1981).

${ }^{14}$ Panis (2003); Fouquereau et al. (2005).
} 
as opposed to abrupt retirement. ${ }^{15}$ To identify the independent effect of gradual as opposed to abrupt transitions to retirement we will need to control for factors identified in the literature as affecting happiness in retirement.

One factor that many studies find has a significant effect on happiness is individuals' sense of control over their life. ${ }^{16}$ In terms of the work-retirement transition, individuals who retired voluntarily are happier than those who were forced out of their job. ${ }^{17}$

Social relationships are another area found to have an impact on happiness. ${ }^{18}$ For example, retirees who are married tend to be happier than those who are single. ${ }^{19}$ The death of a spouse, relative, or close friend and divorce or separation all diminish happiness. ${ }^{20}$ Because of the age of individuals in this study, death of a spouse is a relevant factor that may affect their happiness when transitioning into retirement.

Good health is positively associated with happiness, and health tends to decline as individuals age. ${ }^{21}$ Somewhat surprising, functional limitations, which lead to everyday hassles, are particularly troublesome. They can reduce happiness more than dramatic events, as they limit the ability to perform valued roles and reduce sense of selfefficacy. ${ }^{22}$

Aging alone does not seem to have much of an effect on happiness. After controlling for the decline in health and the loss of social roles and loved ones that comes with aging, neither longitudinal nor cross-sectional studies find a substantial relationship

\footnotetext{
${ }^{15}$ For example, Calvo (2006) and Choi (2001).

${ }^{16}$ Batles and Batles (1986); Lachman and Weaver (1998); Reis, Sheldon, Gable, Roscoe and Ryan (2000); Rodin (1986); Sweeney, Anderson and Bailey (1986). See also literature reviews in DeNeve and Cooper (1998), and Kunzmann, Little and Smith (2002).

${ }^{17}$ Gall, Evans and Howard (1997); Fouquereau, Fernandez and Mullet (1999); Price (2005); Queiroz and Tom (2005); Szinovacz and Davey (2004); Szinovacz and Davey (2005)

${ }^{18}$ Chan and Lee (2006); Cheng and Chan (2006); Diener and Seligman (2004); Glass, De Leon, Bassuk and Berkman (2006); Vanderson and McLaren (2005).

${ }^{19}$ Bierman, Fazio and Milkie (2006); Demo and Acock (1996).

${ }^{20}$ Dulin and Pachana (2005); Lucas, Clark, Georgellis and Diener (2003); Pinquart (2003)

${ }^{21}$ Atchley (1999); Brummett et al. (2001); Cohen (2004); Hilleras, Aguero-Torres and Winblad (2001); Hilleras, Jorm, Herlitz and Bengt (2001); Rohwedder (2006); Rowe and Kahn (1998).

${ }^{22}$ Dulin and Pachana (2005).
} 
between age and happiness in retirement. ${ }^{23}$ An extensive review of literature finds a slight decline in positive affects and a slight rise in negative affects as people age. But essentially all studies find the effects to be small. ${ }^{24}$

Researchers find the effect of income and wealth on happiness somewhat mixed. Cross-sectional studies provide evidence of a positive relationship between wealth and happiness. But researchers analyzing longitudinal data find the effect of income and wealth have on happiness is generally small, except around the poverty threshold. ${ }^{25}$ However, the wealth of an individual approaching and entering retirement may have more of an impact on his happiness. Another economic factor found to effect happiness in retirement is pension type. Some recent research finds that retirees are happier with a defined-benefit pension as opposed to having a comparable amount of wealth in a retirement account. ${ }^{26}$

\section{Data and Methodology}

This study uses data from the Health and Retirement Study (HRS), a nationally representative, biennial, panel survey of older Americans and their spouses. ${ }^{27}$ The HRS began in 1992 and data are available through 2004. The initial HRS cohort was composed of 9,760 age-eligible individuals born between 1931 and 1941 who responded to the HRS in $1992 .^{28}$

\footnotetext{
${ }^{23}$ Cheng (2004); Dulin and Pachana (2005); Jorm (2000); Kunzmann, Little and Smith (2000); Schieman, Van Gundy and Taylor (2002).

${ }^{24}$ Pinquart (2001).

${ }^{25}$ Arendt (2005); Campbell, Converse and Rodgers (1976); Diener and Biswas-Diener (2002); Diener and Seligman (2004); Easterlin (2001); Inglehart and Klingemann (2000); Michalos (1985); Saris (2001). See also literature review in Arthaud-day and Near (2005).

${ }^{26}$ Bender (2004) and Panis (2003).

${ }^{27}$ Many variables used in this project are from the RAND version of the HRS. Variables used that were not available in the RAND version were extracted from the raw datasets and merged with the RAND dataset.

${ }^{28}$ This cut was made using the "rahrsamp" variable (only observations with a value of 1 ) in the RAND version. This corresponds to selecting age-eligible (born 1931-1941) individuals from households originally sampled for the HRS cohort.
} 
The panel nature of the HRS is extremely valuable for a study on the effect of the work-retirement transition on happiness in retirement. Most of the research on happiness in retirement cited above uses cross-sectional studies, which can raise serious concerns about the direction of causation. ${ }^{29}$ This study takes advantage of the longitudinal nature of the HRS to test whether the type of transition out of employment affects an individual's happiness in retirement. We do that by establishing a baseline level of happiness for each individual when they were employed. We then compare that baseline to their happiness when retired. By focusing on the change in happiness we get a far better measure of the effect of a gradual as opposed to abrupt transition into retirement.

Happiness, the focus of our study, is a slippery concept that researchers define in many different ways. By happiness we mean the individual's general experience of different kinds of feelings. Some feelings are pleasurable, such as enjoyment of life. Others, such as sadness, are unpleasant. ${ }^{30}$ To measure happiness we use five questions in the health section of the HRS questionnaire that ask respondents about pleasurable and unpleasant feelings. These are yes-or-no questions, which the HRS asks of both working and retired respondents: "Now think about the past week and the feelings you have experienced. Please tell me if each of the following was true for you much of the time this past week. ... Much of the time... you were happy; you enjoyed life; you felt lonely; you felt depressed; you felt sad.” The first two questions are measures of positive feelings and the last three of negative feelings. ${ }^{31}$

For each individual in the HRS who makes the transition from work to retirement, we measure the change in each of these five happiness indicators (feelings of happiness,

\footnotetext{
${ }^{29}$ The problem in the attribution of causation is highlighted in a study by Charles (2004), which finds a cross-sectional correlation between retirement and feelings of loneliness and depression. But is it retirement that causes these unhappy feelings? The researchers find that unhappy workers, including those suffering a transitory negative shock, are more likely to retire than happy workers. After controlling for this selection, they find that retirement reduces, rather than increases, feelings of loneliness and depression. ${ }^{30}$ Appendix A provides a more detailed discussion of the concept of happiness.

${ }^{31}$ Other researchers studying happiness in retirement often use responses to the HRS inquiring about “satisfaction in retirement.” For example, see Rohwedder (2006), Panis (2003), and Bender (2004). As our study identifies the effect of the retirement transition using change from a baseline, when individuals are working, we could not use this "satisfaction in retirement" variable. There are also important theoretical differences between the two measures discussed in Appendix A.
} 
enjoyment of life, loneliness, depression, and sadness). To do that we take the baseline measure of each indicator in the last wave in which the individual was fully employed and record the change in the first wave in which the individual is fully retired. ${ }^{32}$ As the indicator variables are dichotomous, the value remains the same or changes to the opposite value. We record no change as 0 , a "yes" to "no" change as “-1," and a "no" to "yes" change as "+1." For example, the change in "enjoyment of life" would be -1 if the individual answered "yes" in the last wave of full employment and "no" in the first wave of full retirement; 0 if there was no change, and +1 if the individual said that he did not enjoy life while working, but did in retirement.

Since the values of indicator variables can only be "yes" or "no," the HRS does not reveal a change from "yes" to "more yes," or "no" to "more no." We do not know if an individual who enjoyed (did not enjoy) life while working enjoyed life even more (even less) in retirement. To help address this problem associated with a discrete choice dependent variable, we identify a latent variable, which we call "Affect," that drives all five happiness indicators. The values of the five indicator variables are highly correlated. Respondents who said they were happy also tended to say that they enjoyed life and were not lonely, depressed, nor sad. This common variance suggests that the five HRS variables can be represented as indicators of the latent "Affect" variable. Nearly $60 \%$ of the sample has a positive response to all five indicators in both the last wave of full employment and the first wave of full retirement. But the remainder of the sample has sufficient variance for our latent "Affect" variable to provide a more sensitive measure of the effect of our independent variables on happiness in retirement. One limitation of the latent "Affect" variable is that it represents happiness in a single dimension, losing the ability to discriminate between factors that affect some feelings but not others, primarily

\footnotetext{
${ }^{32}$ Because we wanted to measure the change in happiness between when they were employed and when they first retired, there are differences in the amount of time passing between the measurements among individuals. We include a variable controlling for the number of years from full employment to full retirement which does not have a significant effect on the dependent variables (see Appendix Tables 3, 4, 5, and 6). Additionally, we run our model using a dependent variable that is the difference in happiness between the last wave of full time work and the first wave of transition; see the results section for these estimates.
} 
negative but not positive feelings (or the reverse). Another limitation of the "Affect" variable is interpreting the magnitude of the effects. ${ }^{33}$

We address the problem of interpreting the magnitude of the effects by dividing the sample for each of the five indicator variables in two-those with a "happy" and those with an "unhappy" response when fully employed. Logit regressions on each sample then show the likelihood of the various factors in our analysis causing an increase in happiness (a change in the "negative sample" from an "unhappy" to a "happy" response) or a decrease in happiness (a change in the "positive sample" from a "happy" to an "unhappy" response).

Our primary concern is whether happiness in retirement is affected by a gradual as opposed to a "cold-turkey" transition. To do this, the first task is to identify those individuals in the HRS population who made the transition from work to retirement. We then must classify these individuals into those who retired gradually and those who retired abruptly.

Researchers use a variety of measures to characterize individuals as fully employed, fully retired, or something in-between. Among the most common are hours worked (per week or per year), their self-reported status, whether they have claimed Social Security benefits, and their current wage relative to their peak wage (see Table 1).

To identify individuals in the HRS who made the transition from work to retirement we use two criteria, their usual hours of work per week and self-reported retirement status. ${ }^{34}$ We classify individuals as "fully employed" if they work at least 30 hours per week and report themselves "not retired" (as opposed to "completely retired" or "partly retired"). As illustrated in Figure 1, 5,744 of the 9,760 individuals in the HRS cohort were fully employed in 1992. The final column of this Figure gives the total number fully retired by 2004, the last available wave. We classify individuals as "fully retired” if they have zero hours of work and report themselves "completely retired.” Of

\footnotetext{
${ }^{33}$ For more on the derivation and validity of the latent "Affect” variable see Appendix B.

${ }^{34}$ The usual hours worked per week variable is the sum of usual hours worked per week at his/her main job and the usual hours worked per week at a second job.
} 
the 5,744 individuals who were fully employed in the initial wave, 3,022 had fully retired by $2004 .^{35}$ Of the 3,022 individuals who made a full transition from work to retirement, we have sufficient valid information for 2,389. ${ }^{36}$ Figure 1 also indicates for each wave of the HRS the number of individuals fully employed in 1992 that were: (1) fully retired, (2) not fully retired, or (3) had attrited out of the HRS. ${ }^{37}$

The next task is to classify the 2,389 transitions as gradual or abrupt. As illustrated in Figure 2, we essentially distinguish between the two types of transitions based on the respondent's first self-reported status other than "not retired." If that response is "completely retired" - that is the individual goes from "not retired" to "completely retired" in sequential waves — he is classified as making a cold-turkey transition. We omit from the sample individuals who report themselves as "completely retired" but work more than zero hours, as their employment status in that wave and the nature of their transition are both ambiguous. Respondents whose first self-reported status other than "not retired" is "partly retired" are classified as retiring gradually. We again omit from the sample individuals who report themselves as "completely retired" but work more than zero hours, as their employment status in that wave is ambiguous. We also omit from the sample individuals who reverse direction and report themselves "not retired" after reporting themselves "partly retired", as the nature of their transition is ambiguous. ${ }^{38}$

The two gray rows in Figure 2 designate individuals who transitioned to full retirement at each wave. The gray row at the top indicates the number of workers in each

\footnotetext{
${ }^{35}$ We ignore subsequent labor-market activity once an individual is fully retired. For such individuals, our concern is the effect of their initial transition on their happiness in retirement.

${ }^{36}$ For more details about missing values see Appendix B. Of the 3,022 observations observed transitioning to full retirement, 2,803 could be classified as cold turkey or gradual retirees according to our definitions below. Of those 2,803 observations, 2,389 have valid responses to all five happiness indicators.

${ }^{37}$ In this case, we are taking a sample of those individuals for whom we observe transitioning from fulltime employment to full retirement. These are the only observations that provide information about what affects the change in happiness between these time periods, so this sample may not be representative. ${ }^{38}$ For an individual to be classified as a cold turkey retiree, he or she must have responded "not retired" in every wave prior to the wave designated by our definition (using both self-reported status and hours of work) as his or her first wave of full retirement. For an individual to be classified as a gradual retiree, he or she must have one of more sequential waves with "not retired" responses immediately followed by one or more waves of "partly retired" responses, immediately followed by full retirement using our definition.
} 
wave of the HRS who had retired 'Cold turkey' (being "completely retired” and having been "not retired" in the previous wave). The gray row at the bottom identifies those who had 'Retired gradually' (they are currently "fully retired," but were "partly retired" in the previous wave). By 2004, those retired 'Cold turkey' include 1,733 individuals (73\%), and those 'Retired gradually' include 656 individuals (27\%), for the total sample of 2,389. Figure 2 also reports for each wave the number of respondents still 'Not retired' (self-report as "not retired”) and the number 'Partially retired' (self-report as "partly retired").

We do not consider hours of work in distinguishing between gradual and abrupt retirements for several reasons. As we are primarily interested in individual perceptions of the retirement process, self-reported status is the more relevant single criterion. Moreover, the HRS only asks respondents if they were forced or wanted to retire if they report themselves "completely retired" or "partly retired." So we would not get this information from individuals who work between 0 and 30 hours per week, but consider themselves "not retired." As the voluntary or involuntary nature of a worker's separation from employment has been identified as an important factor contributing to happiness in retirement, we would not be able to include this variable in our analysis had we classified transitions as "gradual" based only on hours of work. ${ }^{39}$

Additional independent variables were included in the regressions. ${ }^{40}$ A set of three dummy variables measuring the respondent's perception on whether retirement was something the respondent "wanted to do," was "part wanted, part forced," or was "forced into.” Included in the regressions are "chose retirement” and "part wanted retirement,"

\footnotetext{
${ }^{39}$ We also experimented with other ways to classify transitions, such as working hours. Based on usual hours worked per week, individuals are coded as a cold turkey retiree if they shift directly from working at 30 or more hours to zero hours. Individuals were coded as a gradual retiree if they reduce work to between 0 and 30 hours before full retirement. Another specification classified gradual retirees as individuals who reduced their hours to less than 30 per week but remained with the same employer before full retirement. Reverse transitions were not allowed in any of these definitions, except if occurring after the first wave of full retirement.

${ }^{40}$ Appendix B contains more details about these variables and the way we handled the remaining missing values.
} 
so estimated the effects are relative to "forced retirement." 41 Feeling forced into retirement is expected to decrease happiness and enjoyment of life and increase loneliness, depression, and sadness.

Our analysis also controls for other factors identified in the literature as affecting happiness at old age:

Death of spouse during the transition. If a respondent has a marital status of “married” or "married, spouse absent” in his last wave of full employment and a marital status of "widowed" in the first wave of full retirement, he or she is coded as having a spouse who died.

Change in health. A change in health status is measured as a change in selfreported health status. Self-reported health status is given on a scale from 1 to 5 , with 1 corresponding to "poor” and 5 to "excellent” health. This variable measures the change in self-reported health status from the last wave of full employment to the wave of full retirement. A positive value for this variable indicates an improvement in health, according to the respondent.

Defined-benefit pension coverage. This reports whether the respondent was covered by a defined-benefit pension plan at their job at the last wave of full employment.

Other control variables included are: the number of years between full employment and full retirement, "unemployment” reported in the first wave of “complete retirement,” and various socioeconomic and demographic variables such as: wealth, type of occupation, education, gender, race and ethnicity (for more details see Appendix C). ${ }^{42}$

\footnotetext{
${ }^{41}$ The wave from which this variable was taken depends on the type of transition. For those coded as cold turkey retirees, this variable is coded based on the individual's response in the first wave of full retirement. For those coded as gradual retirees, this variable is coded using, in this order: (1) if valid, the value of the "wanted to/forced into" variable in the wave immediately following the last wave of full employment (2) otherwise, the first valid response to the "wanted to/forced into" variable after the last wave of full employment and before the first wave of full retirement.

${ }^{42}$ We take the overlap of complete retirement and unemployment to mean that the individual might be somewhat unhappy about also being self-reported as "completely retired."
} 


\section{Results}

Table 2 reports descriptive statistics of the five happiness measures for the overall sample and for the gradual retirement and cold turkey groups, along with group mean or proportion comparison t-tests or chi-squared tests. It shows that there is little change in the positive affect variables taken from the HRS. Both "happiness" and "enjoyment of life” are high when individuals are working, and show slight increases in retirement. The negative affects are generally low, but also increase in retirement. The increases in the negative affects, in feelings of loneliness, depression, and sadness, are also generally larger than the increases in the positive affects. This is reflected in our latent "Affect" variable, which registers a slight decline.

The descriptive statistics, however, generally show no significant difference between the group that retired gradually and those that retired cold-turkey. The one indicator that did register a significant difference was sadness. Workers who retired gradually registered a much larger jump in feelings of sadness.

As shown in Table 3, there are various differences between individuals who retired gradually and those who retired cold-turkey other than the nature of their transition from full employment to complete retirement. More cold-turkey individuals report a high degree of control over their retirement transition and say that they wanted to retire. They were younger, healthier, wealthier, more educated, more likely to be white collar, more likely to have a defined benefit pension, and less likely to report unemployment at the same time they report being fully retired. All of these differences should make the cold-turkey individuals happier than gradual retirees, independent of the way that they retired.

\section{Regression Results}

To identify the effect of gradual as opposed to abrupt transition into retirement, controlling for factors that independently affect happiness, we use three regression specifications. The first set of regressions uses the change in each of the five HRS variables, from the wave when the individual was last fully employed to the first wave when the individual was completely retired, as the dependent variable. As these changes 
can take on three possible values: $(-1,0$, or 1$)$, we use an ordered logit regression. The second set of regressions uses the change in the latent "Affect" variable as the dependent variable. As this change is measured along a continuous scale, we use an ordinary least squares regression. Finally, we divide our sample, for each of the five HRS variables, into those that are initially "happy" and those that are initially "unhappy" and use the change when retired as the dependent variable in a logit regression. The positive (“initially happy”) sample gives a clearer view of factors that tend to diminish "Happiness” and the negative (“initially unhappy”) sample gives a clearer view of factors that tend to increase "Happiness.” The logit regression coefficients also provide a clearer view of the magnitude of the effects of the explanatory factors on the happiness indicators. $^{43}$

The results of the ordered logit regressions on the change in our five happiness measures are reported in Table $4 .{ }^{44}$ The results indicate that cold-turkey retirement (as opposed to the default, gradual retirement) has no significant effect on happiness, enjoyment of life, loneliness, depression, or sadness in retirement. ${ }^{45}$ The results also confirm earlier findings on the effect of other factors identified in the literature as affecting happiness in retirement - the death of a spouse, voluntary as opposed to forced retirement, and health status. Because of the difficulty in interpreting ordered logit coefficients, we focus on the direction and statistical significance of the effect, not on the size of the coefficient.

The death of a spouse had a significant impact on all indicators except depression. Those who lost their spouse are likely to have a decrease in happiness and enjoyment of life and are more likely to have feelings of loneliness and sadness. It is difficult to

\footnotetext{
${ }^{43}$ Note, however that caution should be taken when comparing the magnitude of the effect of an explanatory variable between the two samples. Since these subsamples allow for a different distribution for happiness for each of the two groups, the magnitudes of the coefficients are not directly comparable.

${ }^{44}$ For coefficient estimates for all independent variables included, see Appendix Table 3.

${ }^{45}$ Running these ordered logits on the change in each of the happiness variables between the last wave of full employment and the subsequent wave provides mostly similar results with respect to the type of transition and the voluntary nature of the transition. However, when considering these two periods, there is evidence of significant effects of the type of transition on feeling depressed or sad. Individuals who retire
} 
interpret the ordered logit coefficients as a measure of the size of the effect of each variable on happiness in retirement. However, the size of the coefficient on the death of a spouse suggests it is the largest source of unhappiness in retirement among the factors in our analysis. ${ }^{46}$

Having control over the retirement decision (reporting that retirement was chosen rather than forced) has a significant effect on all HRS indicators except enjoyment of life; however, the direction of the coefficient on enjoyment of life is consistent with the other four measures. Respondents who said retirement was chosen are more likely to have increases in happiness and enjoyment of life and less likely to have increases in loneliness, depression, and sadness, than if their retirement was forced. Even individuals who felt only partly forced into retirement were less likely to be lonelier.

A change in self-reported health status has a significant effect on each of the five indicators. An improvement in health indicates an increase in happiness and in enjoyment of life and a decrease in loneliness, depression, and sadness. All of the coefficients on the change in health status are significant at the 1 percent level, more than either control over the retirement decision or the loss of a spouse. ${ }^{47}$

Surprisingly, the results indicate that coverage by a defined benefit pension has no significant effect on any of the five indicators of happiness in retirement. The results of our regressions using as the dependent variable our latent "Affect" variable are reported in Table $5 .^{48}$ These results are consistent with those of the previous regressions. They show no significant difference between cold-turkey and gradual retirement. Control over

cold-turkey were less likely to record increases in depression and sadness. However, we still find no evidence that the type of transition affects happiness, enjoyment of life, or loneliness.

${ }^{46}$ As indicated on Table 3, very few respondents lost their spouse during the period between being fully employed and completely retired.

47 The coefficients on the health variable are generally smaller than the coefficients on control over the retirement decision or the loss of a spouse. To gauge the indicated effect of health on happiness, however, one needs to multiply this coefficient by the change in self-reported health status, measured on a scale from -4 to 4 . As the mean change in health is -2 , with a standard deviation of 1 , indicated effect of a change in health status is relatively small, relative to the effect of the loss of a spouse or even control over the retirement decision.

${ }^{48}$ For coefficient estimates for all independent variables included, see Appendix Table 4. 
the retirement process, health status, and the death of a spouse have a significant effect on the individual's "Affect". Coverage by a defined benefit plan does not.

Finally, the results of the logit regressions on the divided sample are shown in Tables 6 and $7 .{ }^{49}$ Table 6 shows the results from the "positive sample" (where the value of the variable when the individual was fully employed was "happy") and Table 7 shows the results of the "negative sample" (where the value of the variable when the individual was fully employed was "unhappy"). In both samples, the type of transition to retirement had no significant effect. The small size of the negative sample limits the precision of the parameter estimates and the ability of the regression to produce results that are statistically significant. Nevertheless, the factors identified as significant in the other regressions are generally significant in the positive sample regressions.

The regressions thus provide a much clearer indication of the magnitude of the effect of the various factors. The coefficients reflect the probability that the value of the indicator variable will change (as opposed to remaining the same), with all other variables held at their means. In the positive sample, where more of the results are statistically significant, the coefficient on the loss of a spouse generally has the largest effect on the particular indicator. These results also show control over one's retirement to have a large impact on happiness, even larger (in absolute value) on the depression indicator variable than the loss of a spouse. Control over one's retirement is also the only independent variable to have a statistically significant effect on all five HRS indicator variables in the positive sample. 


\section{Conclusion}

Retirement is a transition between two significantly different stages in an individual's life. A gradual transition gives workers time to shift their daily activities, social relationships, and identity in a more deliberate manner than a cold-turkey transition. And this may help workers to make a better transition to retirement.

Our study, however, finds no evidence of a difference in happiness that can be traced to the type of transition to retirement. Like previous studies, we find that a decline in health status or the loss of a spouse reduces happiness in retirement, and that those who retire because they want to, and not because they are forced, are happier in retirement.

It would seem that this information might alter the plans of workers who currently say they want to retire gradually, rather than all at once. But it may not be the case. We know it generally makes no difference whether we dive straight into a swimming pool or gradually acclimate our body to the water. But whatever the reason, most of us opt for the latter approach. So even if workers accept our results, they still might prefer to exit the labor force gradually.

Our study finds that the nature of our transition—gradual or abrupt—has no effect on our happiness in retirement. But we do find that the sense of control workers have over the transition does have a significant effect. So the ability to retire gradually if we want to-not the effect of the gradual transition per se-should make us happier in retirement. Giving workers a sense of control over their retirement, not necessarily creating gradual retirement paths, should be the item on the policy agenda.

\footnotetext{
${ }^{49}$ For coefficient estimates for all independent variables included, see Appendix Tables 5 and 6.
} 


\section{References}

Albright, Jeremy J. 2006. Confirmatory Factor Analysis Using Amos, LISREL, and MPLUS (Stat/Math Documents). Bloomington, IN: Indiana University.

Allison, Paul D. 2001. Missing Data (Quantitative Applications in the Social Sciences, 07-136). Thousand Oaks, CA: Sage Publications.

Arendt, Jacob N. 2005. "Income and "Outcomes" for Elderly: Do the Poor Have a Poorer Life?" Social Indicators Research 70(3):327-347.

Arthaud-day, Marne and Janet Near. 2005. "The Wealth of Nations and the Happiness of Nations: Why "Accounting" Matters." Social Indicators Research 74(3):511-548.

Atchley, Robert C. 1999. Continuity and Adaptation in Aging: Creating Positive Experiences. Baltimore, MD: Johns Hopkins University Press.

Baltes, Margaret M. and Paul B. Baltes, eds. 1986. The Psychology of Control and Aging. Hillsdale, NJ: Erlbaum.

Bender, Keith A. 2004. “The Well-Being of Retirees: Evidence Using Subjective Data.” Working Paper 2004-24. Chestnut Hill, MA: Center for Retirement Research at Boston College.

Bierman, Alex, Elena M. Fazio and Melissa A. Milkie. 2006. "A Multifaceted Approach to the Mental Health Advantage of the Married: Assessing How Explanations Vary by Outcome Measure and Unmarried Group." Journal of Family Issues 27(4):554582.

Brown, Kathi. 2003. Staying Ahead of the Curve 2003: The AARP Working in Retirement Study. Washington, DC: AARP. 
Brummett, Beverly H., John C. Barefoot, Ilene C. Siegler, Nancy E. Clapp-Channing, Barbara L. Lytle, Hayden B. Bosworth, Williams, Redford B. Jr. and Daniel B. Mark. 2001. "Characteristics of Socially Isolated Patients with Coronary Artery Disease Who Are at Elevated Risk of Mortality." Psychosomatic Medicine 63(2):267-272.

Calvo, Esteban. 2006. “Does Working Longer Make People Healthier and Happier?” Work Opportunity Issue in Brief 2. Chestnut Hill, MA: Center for Retirement Research at Boston College.

Campbell, Angus, Philip E. Converse and Willard R. Rodgers. 1976. The Quality of American Life. New York, NY: Russell Sage Foundation.

Chan, Y. and Rance Lee. 2006. "Network Size, Social Support and Happiness in Later Life: A Comparative Study of Beijing and Hong Kong." Journal of Happiness Studies 7(1):87-112.

Charles, Kerwin K. 2004. "Is Retirement Depressing?: Labor Force Inactivity and Psychological Well-Being in Later Life." P. 269-299 in Accounting for Worker WellBeing, edited by S.W. Polachek ed. Research in Labor Economics, vol. 23. Amsterdam, San Diego and Oxford: Elsevier, JAI.

Chen, Yung-Ping and John C. Scott. 2006. "Phased Retirement: Who Opts For It and Toward What End?” Issue No. 2006-01. Washington, DC: AARP.

Cheng, Sheung-Tak. 2004. "Age and Subjective Well-Being Revisited: A Discrepancy Perspective." Psychology and Aging 19(3):409-415.

Cheng, Sheung-Tak and Alfred C. M. Chan. 2006. "Relationship With Others and Life Satisfaction in Later Life: Do Gender and Widowhood Make a Difference?" Journal of Gerontology B Psychologycal Sciences Social Sciences 61(1):46-53. 
Choi, Namkee G. 2001. "Relationship Between Life Satisfaction and Postretirement Employment Among Older Women." International Journal of Aging and Human Development 52(1):45-70.

Cohen, Sheldon. 2004. "Social Relationship and Health." American Psychologist 59(8):676-684.

Costa, Paul T., Robert R. McCrae and Arthur H. Norris. 1981. "Personal Adjustment to Aging: Longitudinal Prediction from Neuroticism and Extraversion." Journals of Gerontology 36(1):78-85.

Demo, David H. and Alan C. Acock. 1996. "Singlehood, Marriage, and Remarriage: The Effects of Family Structure and Family Relationships on Mothers' Well-Being." Journal of Family Issues 17(3):388-407.

DeNeve, Kristina M. and Harris Cooper. 1998. "The Happy Personality: A MetaAnalysis of 137 Personality Traits and Subjective Well-Being." Psychological Bulletin 124(2):197-229.

Di Tella, Rafael and Robert MacCulloch. 2006. "Some Uses of Happiness Data in Economics." Journal of Economic Perspectives 20(1):25-46.

Diener, Ed. 2000. "Subjective Well-Being: The Science of Happiness and a Proposal for a National Index." American Psychologist 55(1):34-43.

Diener, Ed and Robert Biswas-Diener. 2002. "Will Money Increase Subjective WellBeing?" Social Indicators Research 57(2):119-169.

Diener, Ed and Martin E. P. Seligman. 2004. "Beyond Money: Toward an Economy of Well-Being." Psychological Science in the Public Interest 5(1):1-31.

Dulin, Patrick L. and Nancy A. Pachana. 2005. "Older Adult Mood Functioning: Developmental Changes and Factors Associated with Positive and Negative Outcomes." In Mood State and Health, ed. A.V. Clark, 175-193. Hauppauge, NY: Nova Biomedical Books. 
Easterlin, Richard A. 2001. "Life Cycle Welfare: Trends and Differences." Journal of Happiness Studies 2(1):1-12.

Erickson, Erik H., Joan M. Erikson and Helen Q. Kivnick. 1986. Vital Involvement in Old Age. New York, NY: Norton.

Everard, Kelly M., Helen W. Lach, Edwin B. Fisher and Carolyn M. Baum. 2000.

"Relationship of Activity and Social Supports to the Functional Health of Older Adults." Journal of Gerontology B: Social Sciences 55B(4):S208-S212.

Fouquereau, Evelyne, Anne Fernandez, Antonio M. Fonseca, Maria C. Paul and Virpi Uotinen. 2005. "Perceptions of and Satisfaction With Retirement: A Comparison of Six European Union Countries." Psychology and Aging 20(3):524-528.

Fouquereau, Evelyne, Anne Fernandez and Etienne Mullet. 1999. "The Retirement Satisfaction Inventory: Factor structure in a French sample." European Journal of Psychological Assessment 15(1):49-56.

Frey, Bruno S. and Alois Stutzer. 2002. "What Can Economists Learn from Happiness Research?" Journal of Economic Literature 40(2):402-435.

Gall, Terry L., David R. Evans and John Howard. 1997. "The Retirement Adjustment Process: Changes in the Well-Being of Male Retirees Across Time." Journals of Gerontology: Series B: Psychological Sciences and Social Sciences 52(3):P110P117.

Gilbert, Daniel. 2007. Stumbling on Happiness. New York, NY: Vintage Books.

Glass, Thomas A., Mendes De Leon,Carlos F., Shari S. Bassuk and Lisa F. Berkman. 2006. "Social Engagement and Depressive Symptoms in Late Life: Longitudinal Findings." Journal of Aging and Health 18(4):604-628.

Gustman, Alan L. and Thomas L. Steinmeier. 2007. "Projecting Behavioral Responses to the Next Generation of Retirement Policies.” NBER Working Paper 12958. Cambridge, MA: National Bureau of Economic Research. 
------. 2000. "Retirement Outcomes in the Health and Retirement Study.” Working Paper 7588. Cambridge, MA: NBER.

------. 1984. "Partial Retirement and the Analysis of Retirement Behavior." Industrial and Labor Relations Review 37(April):403-415.

Haider, Steven and David Loughran. 2001. “Elderly Labor Supply: Work or Play?” Working Paper 2001-04. Chestnut Hill, MA: Center for Retirement Research at Boston College.

Hilleras, Pernilla K., Hedda Aguero-Torres and Bengt Winblad. 2001. "Factors Influencing Well-Being in the Elderly." Current Opinion in Psychiatry 14(4):361365.

Hilleras, Pernilla K., Anthony F. Jorm, Agneta Herlitz and Bengt Winblad. 2001. "Life Satisfaction Among the Very Old: A Survey on a Cognitively Intact Sample Aged 90 Years or Above." International Journal of Aging and Human Development 52(1):7190.

Honig, Marjorie and Giora Hanoch. 1985. "Partial Retirement as a Separate Mode of Retirement Behavior." The Journal of Human Resources 20(1):21-46.

Hutchens, Robert. 2007. "Phased Retirement: Problems and Prospects.” Issue in Brief 8. Chestnut Hill, MA: Center for Retirement Research at Boston College.

Hutchens, Robert and Kerry L. Papps. 2005. "Developments in Phased Retirement." In Reinventing the Retirement Paradigm, eds. R.L. Clark and O.S. Mitchell, 287. New York, NY: Oxford University Press.

Inglehart, Ronald and Hans-Dieter Klingemann. 2000. "Genes, Culture, Democracy, and Happiness." In Culture and Subjective Well-Being, eds. E. Diener and E.M. Suh P, 165-183. Cambridge, MA: The MIT Press. 
Jöreskog, Karl G. 2005[2002]. Structural Equation Modeling With Ordinal Variables Using LISREL (Karl's Corner Documents). Lincolnwood, IL: Scientific Software International, Inc.

Jöreskog, Karl G. and Dag Sörbom. 1996a. LISREL 8 User's Reference Guide.

Lincolnwood, IL: Scientific Software International, Inc.

------. 1996b. PRELIS 2 User's Reference Guide. Lincolnwood, IL: Scientific Software International, Inc.

Jorm, A. F. 2000. "Does Old Age Reduce the Risk of Anxiety and Depression? A Review of Epidemiological Studies Across the Adult Life Span." Psychological Medicine 30(1):11-22.

Kahneman, Daniel and Alan B. Krueger. 2006. "Developments in the Measurement of Subjective Well-Being." Journal of Economic Perspectives 20(1):3-24.

Kunzmann, Ute, Todd D. Little and Jacqui Smith. 2000. "Is Age-Related Stability of Subjective Well-Being a Paradox?: Cross-Sectional and Longitudinal Evidence From the Berlin Aging Study." Psychology and Aging 15(3):511-526.

Kunzmann, Ute, Todd Little and Jacqui Smith. 2002. "Perceiving Control: A DoubleEdged Sword in Old Age." Journals of Gerontology: Series B: Psychological Sciences and Social Sciences 57B(6):484-P491.

Lachman, Margie E. and Suzanne L. Weaver. 1998. "The Sense of Control as a Moderator of Social Class Differences in Health and Well-Being." Journal of Personality and Social Psychology 74(3):763-773.

Layard, Richard. 2005. Happiness. Lessons From a New Science. New York, NY: The Penguin Press.

Lucas, Richard E., Andrew E. Clark, Yannis Georgellis and Ed Diener. 2003.

"Reexamining Adaptation and the Set Point Model of Happiness: Reactions to 
Changes in Marital Status." Journal of Personality and Social Psychology 84(3):527539.

Michalos, Alex C. 1985. "Multiple Discrepancies Theory (MDT)." Social Indicators Research 16(4):347-413.

Panis, Constantijn. 2003. “Annuities and Retirement Satisfaction.” Working Paper 03-17 DRU 3021. RAND Corporation.

Pinquart, Martin. 2003. "Loneliness in Married, Widowed, Divorced, and Never-Married Older Adults." Journal of Social and Personal Relationships 20(1):31-53.

------. 2001. "Age Differences in Perceived Positive Affect, Negative Affect, and Affect Balance in Middle and Old Age." Journal of Happiness Studies 2(4):375-405.

Price, Christine A. and Eunjee Joo. 2005. "Exploring the Relationship Between Marital Status and Women's Retirement Satisfaction." International Journal of Aging \& Human Development 61(1):37-55.

Queiroz, Bernardo L. and Sarah E. Tom. 2005. "How Does Voluntary and Involuntary Retirement Affect Psychological Well-Being and Health Status in Later Life." Population Association of America 2006 Annual Meeting Program. Los Angeles, California March 30 - April 1.

RAND Center for the Study of Aging. 2007. "RAND HRS Data, Version G.". Retrieved May 2007. Available at: http://hrsonline.isr.umich.edu.

Rehberg, Karl-Siegbert. 2000. "The Fear of Happiness: Anthropological Motives." Journal of Happiness Studies 1(4):479-500.

Reis, Harry T., Kennon M. Sheldon, Shelly L. Gable, Joseph Roscoe and Richard M. Ryan. 2000. "Daily Well-Being: The Role of Autonomy, Competence, and Relatedness." Personality and Social Psychology Bulletin 26(4):419-435. 
Rodin, Judith. 1986. "Aging and Health: Effects of the Sense of Control." Science 233(4770):1271-1276.

Rohwedder, Susann. 2006. "Self-Assessed Retirement Outcomes: Determinants and Pathways.” Working Paper 2006-141. Ann Arbor, MI: University of Michigan, Michigan Retirement Research Center.

Rowe, John W. and Robert L. Kahn. 1998. Successful Aging. New York: Pantheon.

Royston, Patrick. 2004. "Multiple Imputation of Missing Values." Stata Journal 4(3):277-241.

Ruhm, Christopher J. 1990. "Bridge Jobs and Partial Retirement." Journal of Labor Economics 8(4):482-501.

Saris, Willem E. 2001. "The Relationship between Income and Satisfaction: The Effect of Measurement Error and Suppressor Variables." Social Indicators Research 53(2):117-136.

Schieman, Scott, Karen Van Gundy and John Taylor. 2002. "The Relationship Between Age and Depressive Symptoms: A Test of Competing Explanatory and Suppression Influences." Journal of Aging and Health 14(2):260-285.

Siegrist, Johannes, Olaf Von dem Knesebeck and Craig E. Pollack. 2004. "Social Productivity and Well-Being of Older People: A Sociological Exploration." Social Theory \& Health 2(1):1-17.

Sweeney, Paul D., Karen Anderson and Scott Bailey. 1986. "Attributional Style in Depression: A Meta-Analytic Review." Journal of Personality and Social Psychology 50(5):974-991.

Szinovacz, Maximiliane E. and Adam Davey. 2005. "Predictors of Perceptions of Involuntary Retirement." The Gerontologist 45(1):36-47. 
------. 2004. "Retirement Transitions and Spouse Disability: Effects on Depressive Symptoms." Journals of Gerontology: Series B: Psychological Sciences and Social Sciences 59B(6):S333-S342.

University of Michigan. "Health and Retirement Study, 1992-2004.". Retrieved May 2007. Available at: http://hrsonline.isr.umich.edu.

US General Accounting Office. 2001. Older Workers: Demographic Trends Pose Challenges for Employers and Workers (General Accounting Office Report GAO02-85). Washington, DC: US General Accounting Office.

Vanderhorst, R. K. and S. McLaren. 2005. "Social Relationships as Predictors of Depression and Suicidal Ideation in Older Adults." Aging \& Mental Health 9(6):517525.

Veenhoven, Ruut. 2006. "Happiness in Nations, Introductory Text." Rotterdam, Netherlands: World Database of Happiness, Erasmus University Rotterdam, Retrieved 6/29, 2006. Available at:

http://www1.eur.nl/fsw/happiness/hap_nat/introtexts/intronat-contents.html.

------. 2002. "Why Social Policy Needs Subjective Indicators." Social Indicators Research 58(1):33-46.

------. 2000. "The Four Qualities of Life: Ordering Concepts and Measures of the Good Life." Journal of Happiness Studies 1(1):1-39.

------. 1991. "Is Happiness Relative?" Social Indicators Research 24(1):1-34.

Watson Wyatt. 2004. Phased Retirement Aligning Employer Programs with Worker Preferences. Washington, DC: Watson Wyatt Worldwide. 
Table 1. Comparison of studies of gradual retirement ${ }^{1}$

\begin{tabular}{|c|c|c|}
\hline Study & $\begin{array}{l}\text { Definition of gradual } \\
\text { retirement }\end{array}$ & $\begin{array}{l}\% \text { found to be } \\
\text { gradually retired }\end{array}$ \\
\hline Gustman and Steinmeier (1984) ${ }^{*}$ & Self-reported status & $33 \%$ \\
\hline Honig and Hanoch (1985) ${ }^{*}$ & $\begin{array}{l}\text { Earnings }<50 \% \text { of maximum } \\
\text { career earnings }\end{array}$ & $19.7 \%$ \\
\hline Ruhm (1990) ${ }^{*}$ & $\begin{array}{l}\text { Earnings and self-reported } \\
\text { status }\end{array}$ & $6.2 \%$ to $50+\%$ \\
\hline \multirow{7}{*}{ Gustman and Steinmeier (2000) $^{* *}$} & Self-reported status & $6.6 \%$ to $12.9 \%$ \\
\hline & $\begin{array}{l}\text { Usual hours worked per } \\
\text { week (1-24) }\end{array}$ & $7.6 \%$ to $10.2 \%$ \\
\hline & $\begin{array}{l}\text { Usual hours worked per year } \\
(1-1,999)\end{array}$ & $8.6 \%$ to $10.9 \%$ \\
\hline & $\begin{array}{l}\text { By leaving } 10 \text { or more year } \\
\text { job }\end{array}$ & $22.7 \%$ to $26.0 \%$ \\
\hline & $\begin{array}{l}\text { By leaving } 20 \text { or more year } \\
\text { job }\end{array}$ & $19.1 \%$ to $23.8 \%$ \\
\hline & By change in hourly wage & $10.1 \%$ to $12.6 \%$ \\
\hline & $\begin{array}{l}\text { By change in weekly } \\
\text { earnings }\end{array}$ & $11.7 \%$ to $15.6 \%$ \\
\hline Haider and Loughran $(2001)^{* * *}$ & $\begin{array}{l}\text { Less than } 1,750 \text { hours } \\
\text { annually }\end{array}$ & $22 \%$ to $72 \%$ \\
\hline Chen and Scott (2006) ${ }^{* *}$ & $\begin{array}{l}\text { Self-reported status and } \\
15 \%-99 \% \text { hours reduction }\end{array}$ & $3 \%$ to $19 \%$ \\
\hline This study $^{* *}$ & Self-reported status & $27 \%$ \\
\hline
\end{tabular}

${ }^{1}$ Adapted from Chen and Scott (2006).

* Data drawn from the SSA Retirement History Study.

** Data drawn from the HRS.

${ }^{* * *}$ Data drawn from the CPS. 
Table 2. Descriptive Statistics for Five Happiness Indicators and Latent Affect by Type of Retirement Transition

\begin{tabular}{|c|c|c|c|c|c|c|c|}
\hline \multirow[b]{2}{*}{ Variable } & \multirow[b]{2}{*}{ Metric } & \multicolumn{2}{|c|}{$\begin{array}{c}\text { All } \\
(\mathrm{N}=2,389) \\
\end{array}$} & \multicolumn{2}{|c|}{$\begin{array}{l}\text { Phased } \\
(\mathrm{N}=656)\end{array}$} & \multicolumn{2}{|c|}{$\begin{array}{l}\text { Cold Turkey } \\
(\mathrm{N}=1,733)\end{array}$} \\
\hline & & Mean & Std. Dev. & Mean & Std. Dev. & Mean & Std. Dev. \\
\hline Happiness $_{\mathrm{t} 1}$ & $0=$ no; $1=$ yes & 0.874 & 0.331 & 0.861 & 0.346 & 0.879 & 0.326 \\
\hline Happiness $_{\mathrm{t} 2}$ & $0=$ no; $1=y e s$ & 0.883 & 0.321 & 0.875 & 0.331 & 0.886 & 0.318 \\
\hline Change in Happiness & $-1=$ less; $0=e q u a l ; 1=$ more & 0.009 & 0.404 & 0.014 & 0.408 & 0.007 & 0.402 \\
\hline Enjoyment of Life ${ }_{t 1}$ & $0=$ no; $1=$ yes & 0.930 & 0.256 & 0.916 & 0.277 & 0.935 & 0.247 \\
\hline Enjoyment of Life $\mathrm{t}_{\mathrm{t} 2}$ & $0=$ no; $1=y e s$ & 0.933 & 0.251 & 0.918 & 0.275 & 0.938 & 0.241 \\
\hline Change in Enjoyment of Life & -1=less; 0=equal; 1=more & 0.003 & 0.312 & 0.002 & 0.343 & 0.003 & 0.300 \\
\hline Loneliness $_{\mathrm{t} 1}$ & $0=$ no; $1=y e s$ & 0.107 & 0.309 & 0.107 & 0.309 & 0.107 & 0.309 \\
\hline Loneliness $_{\mathrm{t} 2}$ & $0=$ no; $1=y e s$ & 0.151 & 0.358 & 0.152 & 0.360 & 0.150 & 0.357 \\
\hline Change in Loneliness & $-1=$ less; $0=$ equal; $1=$ more & 0.044 & 0.394 & 0.046 & 0.384 & 0.043 & 0.398 \\
\hline Depression $_{\mathrm{t} 1}$ & $0=$ no; $1=y e s$ & 0.118 & 0.323 & 0.120 & 0.326 & 0.118 & 0.322 \\
\hline Depression $_{\mathrm{t} 2}$ & $0=$ no; $1=$ yes & 0.154 & 0.361 & 0.165 & 0.371 & 0.149 & 0.357 \\
\hline Change in Depression & $-1=$ less; $0=$ equal; $1=$ more & 0.035 & 0.413 & 0.044 & 0.413 & 0.032 & 0.413 \\
\hline Sadness $_{\mathrm{t} 1}$ & $0=$ no; $1=y e s$ & 0.121 & 0.327 & $0.093^{\star *}$ & 0.291 & $0.132^{\star *}$ & 0.339 \\
\hline Sadness $_{\mathrm{t} 2}$ & $0=$ no; $1=y e s$ & 0.172 & 0.378 & 0.184 & 0.388 & 0.168 & 0.374 \\
\hline Change in Sadness & $-1=$ less; $0=$ equal; $1=$ more & 0.051 & 0.436 & $0.091 * *$ & 0.436 & $0.036^{\star *}$ & 0.435 \\
\hline Latent Affect $t_{t 1}$ & -0.714 to 0.506 & 0.295 & 0.230 & 0.295 & 0.228 & 0.295 & 0.231 \\
\hline Affect $_{\mathrm{t} 2}$ & -0.695 to 0.474 & 0.273 & 0.259 & 0.264 & 0.269 & 0.276 & 0.256 \\
\hline Change in Affect & -0.931 to 0.812 & -0.022 & 0.237 & -0.031 & 0.242 & -0.018 & 0.235 \\
\hline
\end{tabular}

Notes: ${ }_{\mathrm{t} 1}=$ last wave of full employment; ${ }_{\mathrm{t} 2}=$ first wave of full retirement.

${ }^{\star} p<.05 ;{ }^{* \star} p<.01 ;{ }^{* \star *} p<.001$ (two tailed t tests and chi-squared tests reported, denoting statistically significant differences between the two types of transition groups.) 
Table 3. Descriptive Statistics for the Independent Variables by Type of Retirement Transition

\begin{tabular}{|c|c|c|c|c|c|c|c|}
\hline \multirow[b]{2}{*}{ Variable } & \multirow[b]{2}{*}{ Metric } & \multicolumn{2}{|c|}{$\begin{array}{c}\text { All } \\
(\mathrm{N}=2,389)\end{array}$} & \multicolumn{2}{|c|}{$\begin{array}{l}\text { Phased } \\
(\mathrm{N}=656)\end{array}$} & \multicolumn{2}{|c|}{$\begin{array}{l}\text { Cold Turkey } \\
(\mathrm{N}=1,733)\end{array}$} \\
\hline & & Mean & Std. Dev. & Mean & Std. Dev. & Mean & Std. Dev. \\
\hline Retirement Wanted & $0=$ no; $1=y e s$ & 0.643 & 0.479 & $0.581^{\star \star \star}$ & 0.494 & $0.667^{\star \star \star}$ & 0.471 \\
\hline Retirement Partly Wanted/Forced & $0=$ no; $1=y e s$ & 0.089 & 0.284 & 0.079 & 0.270 & 0.092 & 0.290 \\
\hline Retirement Forced & $0=$ no; $1=y e s$ & 0.268 & 0.443 & $0.340^{\star \star *}$ & 0.474 & $0.241^{\star \star *}$ & 0.428 \\
\hline Spouse Death & $0=$ no; $1=y e s$ & 0.023 & 0.151 & $0.034^{\star}$ & 0.180 & $0.020^{*}$ & 0.139 \\
\hline Improved Health & -4 (deteriorated) to 4 (improved) & -0.222 & 1.003 & $-0.320^{\star *}$ & 1.027 & $-0.185^{\star \star}$ & 0.991 \\
\hline Any DB & $0=$ no; $1=y e s$ & 0.517 & 0.500 & $0.375^{\star \star \star}$ & 0.484 & $0.570^{\star \star *}$ & 0.495 \\
\hline $\mathrm{Age}_{\mathrm{t} 1}$ & 50 to 71 years & 59.56 & 3.338 & $58.73^{\star \star \star}$ & 3.392 & $59.88^{\star \star *}$ & 3.264 \\
\hline Age $_{\mathrm{t} 2}$ & 52 to 73 years & 62.58 & 3.417 & $64.02^{\star \star \star}$ & 3.434 & $62.04^{\star \star \star}$ & 3.250 \\
\hline Years Between Emp. and Ret. & 1 to 12 years & 3.019 & 1.849 & $5.284^{\star \star \star}$ & 1.884 & $2.162^{\star \star \star}$ & 0.834 \\
\hline Male & $0=$ no; $1=y e s$ & 0.494 & 0.500 & 0.492 & 0.500 & 0.495 & 0.500 \\
\hline White Non-Hispanic & $0=$ no; $1=y e s$ & 0.316 & 0.465 & 0.294 & 0.456 & 0.324 & 0.468 \\
\hline Log of Mean Wealth & 0 to 18.765 (real \$USD, 2003) & 10.549 & 3.180 & $10.284^{\star}$ & 3.593 & $10.649^{\star}$ & 3.004 \\
\hline More than High School & $0=$ no; $1=y e s$ & 0.390 & 0.488 & $0.378^{\star}$ & 0.485 & $0.395^{\star}$ & 0.489 \\
\hline Blue-Collar & $0=$ no; $1=y e s$ & 0.299 & 0.458 & 0.305 & 0.461 & 0.297 & 0.457 \\
\hline Unemployed & $0=$ no; $1=y e s$ & 0.005 & 0.068 & 0.003 & 0.055 & 0.005 & 0.072 \\
\hline
\end{tabular}

Notes: ${ }_{\mathrm{t} 1}=$ last wave of full employment; ${ }_{\mathrm{t} 2}=$ first wave of full retirement. These summary statistics include both recorded and imputed values.

${ }^{*} p<.05 ;{ }^{* \star} p<.01 ;{ }^{* \star \star} p<.001$ (two tailed t tests and chi-squared tests reported, denoting statistically significant differences between the two types of transition groups.) 
Table 4. Ordered Logit Results on Five Indicator Variables $(N=2,389)$

\begin{tabular}{|c|c|c|c|c|c|}
\hline \multicolumn{6}{|c|}{$\begin{array}{ll} & \text { Enjoy }\end{array}$} \\
\hline & Happy & Life & Lonely & Depressed & Sad \\
\hline Cold Turkey Retirement & $\begin{array}{l}0.086 \\
(0.19)\end{array}$ & $\begin{array}{l}0.262 \\
(0.23)\end{array}$ & $\begin{array}{c}-0.058 \\
(0.19)\end{array}$ & $\begin{array}{l}0.236 \\
(0.18)\end{array}$ & $\begin{array}{c}-0.101 \\
(0.17)\end{array}$ \\
\hline Retirement Wanted & $\begin{array}{c}0.481^{\star \star} \\
(0.16)\end{array}$ & $\begin{array}{l}0.250 \\
(0.18)\end{array}$ & $\begin{array}{c}-0.633^{\star \star \star} \\
(0.14)\end{array}$ & $\begin{array}{c}-0.470 * * \\
(0.15)\end{array}$ & $\begin{array}{c}-0.443^{\star \star} \\
(0.14)\end{array}$ \\
\hline Retirement Partly Wanted & $\begin{array}{l}0.095 \\
(0.25)\end{array}$ & $\begin{array}{l}0.263 \\
(0.29)\end{array}$ & $\begin{array}{c}-0.917^{\star * *} \\
(0.24)\end{array}$ & $\begin{array}{c}-0.150 \\
(0.22)\end{array}$ & $\begin{array}{r}-0.262 \\
(0.22)\end{array}$ \\
\hline Spouse Death & $\begin{array}{c}-1.110^{\star \star} \\
(0.34)\end{array}$ & $\begin{array}{c}-1.462^{\star \star \star} \\
(0.38)\end{array}$ & $\begin{array}{c}2.493^{\star \star \star} \\
(0.30)\end{array}$ & $\begin{array}{l}0.235 \\
(0.35)\end{array}$ & $\begin{array}{l}0.707^{\star} \\
(0.31)\end{array}$ \\
\hline Improved Health & $\begin{array}{c}0.262^{\star * \star} \\
(0.06)\end{array}$ & $\begin{array}{c}0.354^{\star \star \star} \\
(0.07)\end{array}$ & $\begin{array}{c}-0.160 \text { ** } \\
(0.06)\end{array}$ & $\begin{array}{c}-0.282^{\star \star \star} \\
(0.05)\end{array}$ & $\begin{array}{c}-0.231^{\star \star \star} \\
(0.05)\end{array}$ \\
\hline Any DB & $\begin{array}{c}-0.037 \\
(0.12)\end{array}$ & $\begin{array}{l}0.016 \\
(0.15)\end{array}$ & $\begin{array}{l}0.128 \\
(0.12)\end{array}$ & $\begin{array}{l}0.059 \\
(0.12)\end{array}$ & $\begin{array}{l}0.042 \\
(0.11)\end{array}$ \\
\hline Log Likelihood & -1295 & -895 & -1223 & -1334 & -1440 \\
\hline
\end{tabular}

Note : Change from the last wave of full employment to the first wave of full retirement. Regular oredered logit regression coefficients reported for the indicator variables. The standard errors are in parentheses. All five models control for demographic and socioeconomic variables. For the full results see Appendix Table 3.

${ }^{\star} p<.05 ;{ }^{*} p<.01 ; * \star * p<.001$ (two tailed tests for all variables). 
Table 5. Regression Results on Latent "Affect" $(\mathrm{N}=2,389)$

\begin{tabular}{lc}
\hline \hline & Latent \\
\hline "Affect" \\
\hline Cold Turkey Retirement & 0.002 \\
& $(0.020)$ \\
Retirement Wanted & $0.056^{\star \star \star}$ \\
& $(0.010)$ \\
Retirement Partly Wanted & $0.045^{\star}$ \\
& $(0.020)$ \\
Spouse Death & $-0.157^{\star \star \star}$ \\
& $(0.030)$ \\
Improved Health & $0.034^{\star \star *}$ \\
Any DB & $(0.000)$ \\
& -0.004 \\
$\mathrm{R}^{2}$ & $(0.010)$ \\
\hline
\end{tabular}

Note: Change from the last wave of full employment to the first wave of full retirement. Unstandardized regression coefficients reported. The standard errors are in parentheses. The model controls for demographic and socioeconomic variables. For the full results see Appendix Table 4.

${ }^{\star} p<.05 ;{ }^{* \star} p<.01 ;{ }^{* \star} p<.001$ (two tailed tests for all variables). 
Table 6. Logit Marginal Effects on Five Indicator Variables for Positive Sample

\begin{tabular}{|c|c|c|c|c|c|}
\hline & $\begin{array}{c}\text { Happy } \\
\text { to } \\
\text { Not-Happy } \\
\end{array}$ & $\begin{array}{c}\text { Enjoy Life } \\
\text { to } \\
\text { Not-Enjoy Life }\end{array}$ & 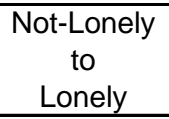 & $\begin{array}{c}\text { Not-Depressed } \\
\text { to } \\
\text { Depressed } \\
\end{array}$ & $\begin{array}{c}\text { Not-Sad } \\
\text { to } \\
\text { Sad } \\
\end{array}$ \\
\hline Cold Turkey Retirement & $\begin{array}{l}0.010 \\
(0.02)\end{array}$ & $\begin{array}{l}-0.013 \\
(0.01)\end{array}$ & $\begin{array}{l}0.010 \\
(0.02)\end{array}$ & $\begin{array}{l}0.027 \\
(0.02)\end{array}$ & $\begin{array}{c}0.01 \\
(0.02)\end{array}$ \\
\hline Retirement Wanted & $\begin{array}{c}-0.087^{\star \star \star} \\
(0.02)\end{array}$ & $\begin{array}{c}-0.047^{\star * *} \\
(0.01)\end{array}$ & $\begin{array}{c}-0.084^{\star \star \star} \\
(0.02)\end{array}$ & $\begin{array}{c}-0.087^{\star \star \star} \\
(0.02)\end{array}$ & $\begin{array}{c}-0.086^{\star * *} \\
(0.02)\end{array}$ \\
\hline Retirement Partly Wanted & $\begin{array}{r}-0.020 \\
(0.01)\end{array}$ & $\begin{array}{c}-0.024^{\star \star} \\
(0.01)\end{array}$ & $\begin{array}{c}-0.046 \text { ** } \\
(0.02)\end{array}$ & $\begin{array}{l}-0.022 \\
(0.02)\end{array}$ & $\begin{array}{r}-0.030 \\
(0.02)\end{array}$ \\
\hline Spouse Death & $\begin{array}{l}0.135^{\star} \\
(0.06)\end{array}$ & $\begin{array}{l}0.125^{\star} \\
(0.05)\end{array}$ & $\begin{array}{c}0.478 * \star \star \\
(0.08)\end{array}$ & $\begin{array}{l}0.046 \\
(0.04)\end{array}$ & $\begin{array}{l}0.117^{*} \\
(0.06)\end{array}$ \\
\hline Improved Health & $\begin{array}{c}-0.017^{* \star *} \\
(0.00)\end{array}$ & $\begin{array}{c}-0.014^{\star \star \star} \\
(0.00)\end{array}$ & $\begin{array}{l}-0.010 \\
(0.01)\end{array}$ & $\begin{array}{c}-0.024^{\star \star *} \\
(0.01)\end{array}$ & $\begin{array}{c}-0.025^{\star \star \star} \\
(0.01)\end{array}$ \\
\hline Any DB & $\begin{array}{l}0.028^{*} \\
(0.01)\end{array}$ & $\begin{array}{l}0.012 \\
(0.01)\end{array}$ & $\begin{array}{l}0.004 \\
(0.01)\end{array}$ & $\begin{array}{l}0.013 \\
(0.01)\end{array}$ & $\begin{array}{l}0.019 \\
(0.01)\end{array}$ \\
\hline Log Likelihood & -665.1 & -678.6 & -774.6 & -678.6 & -774.6 \\
\hline $\mathrm{N}$ & 2089 & 2221 & 2134 & 2106 & 2099 \\
\hline
\end{tabular}

Note: The "positive sample" includes only individuals starting with positive affects at the last wave of full employment. The coefficients reflect the probability of a negative change in each indicator variable (as opossed to no change) from the last wave of full employment to the first wave of full retirement, with all variables held at their means. The standard errors are in parentheses. All models control for demographic and socioeconomic variables. For the full results see Apendix Table 5.

${ }^{*} p<.05 ;{ }^{* *} p<.01 ;{ }^{* *} p<.001$ (two tailed tests for all variables). 
Table 7. Logit Marginal Effects on Five Indicator Variables for Negative Sample

\begin{tabular}{|c|c|c|c|c|c|}
\hline & $\begin{array}{c}\text { Not-Happy } \\
\text { to } \\
\text { Happy } \\
\end{array}$ & $\begin{array}{c}\text { Not-Enjoy Life } \\
\text { to } \\
\text { Enjoy Life } \\
\end{array}$ & $\begin{array}{c}\begin{array}{c}\text { Lonely } \\
\text { to } \\
\text { Not-Lonely }\end{array} \\
\end{array}$ & $\begin{array}{c}\text { Depressed } \\
\text { to } \\
\text { Not-Depressed } \\
\end{array}$ & $\begin{array}{c}\text { Sad } \\
\text { to } \\
\text { Not-Sad }\end{array}$ \\
\hline Cold Turkey Retirement & $\begin{array}{l}0.009 \\
(0.09)\end{array}$ & $\begin{array}{l}0.090 \\
(0.11)\end{array}$ & $\begin{array}{l}0.191 \\
(0.12)\end{array}$ & $\begin{array}{r}-0.034 \\
(0.11)\end{array}$ & $\begin{array}{l}0.098 \\
(0.13)\end{array}$ \\
\hline Retirement Wanted & $\begin{array}{c}0.227^{\star \star \star} \\
(0.06)\end{array}$ & $\begin{array}{c}0.258^{\star \star \star} \\
(0.08)\end{array}$ & $\begin{array}{l}0.160 \\
(0.08)\end{array}$ & $\begin{array}{c}0.262^{\star * *} \\
(0.07)\end{array}$ & $\begin{array}{c}0.240 \star \star \star \\
(0.07)\end{array}$ \\
\hline Retirement Partly Wanted & $\begin{array}{l}0.115 \\
(0.09)\end{array}$ & $\begin{array}{l}0.047 \\
(0.12)\end{array}$ & $\begin{array}{l}0.284 * \\
(0.11)\end{array}$ & $\begin{array}{l}0.201 * \\
(0.10)\end{array}$ & $\begin{array}{l}0.225^{\star} \\
(0.09)\end{array}$ \\
\hline Spouse Death & $\begin{array}{l}-0.242 \\
(0.19)\end{array}$ & $\begin{array}{l}-0.350 \\
(0.23)\end{array}$ & $\begin{array}{l}0.055 \\
(0.24)\end{array}$ & $\begin{array}{l}0.109 \\
(0.17)\end{array}$ & $\begin{array}{l}-0.286 \\
(0.17)\end{array}$ \\
\hline Improved Health & $\begin{array}{l}0.041 \\
(0.03)\end{array}$ & $\begin{array}{l}0.032 \\
(0.03)\end{array}$ & $\begin{array}{l}0.086 * \\
(0.04)\end{array}$ & $\begin{array}{l}0.049 \\
(0.03)\end{array}$ & $\begin{array}{l}0.028 \\
(0.03)\end{array}$ \\
\hline Any DB & $\begin{array}{c}-0.044 \\
(0.06)\end{array}$ & $\begin{array}{l}0.118 \\
(0.08)\end{array}$ & $\begin{array}{l}0.039 \\
(0.07)\end{array}$ & $\begin{array}{l}0.059 \\
(0.07)\end{array}$ & $\begin{array}{l}0.092 \\
(0.07)\end{array}$ \\
\hline Log Likelihood & -170.6 & -84.4 & -158.9 & -160.9 & -174.9 \\
\hline$N$ & 300 & 168 & 255 & 283 & 290 \\
\hline
\end{tabular}

Note: The "negative sample" includes only individuals starting with negative affects at the last wave of full employment. The coefficients reflect the likelihood of a positive change in each indicator variable (as opossed to no change) from the last wave of full employment to the first wave of full retirement, with all variables held at their means. The standard errors are in parentheses. All models control for demographic and socioeconomic variables. For the full results see Appendix Table 6.

${ }^{*} p<.05 ;{ }^{* *} p<.01 ;{ }^{* *} p<.001$ (two tailed tests for all variables). 


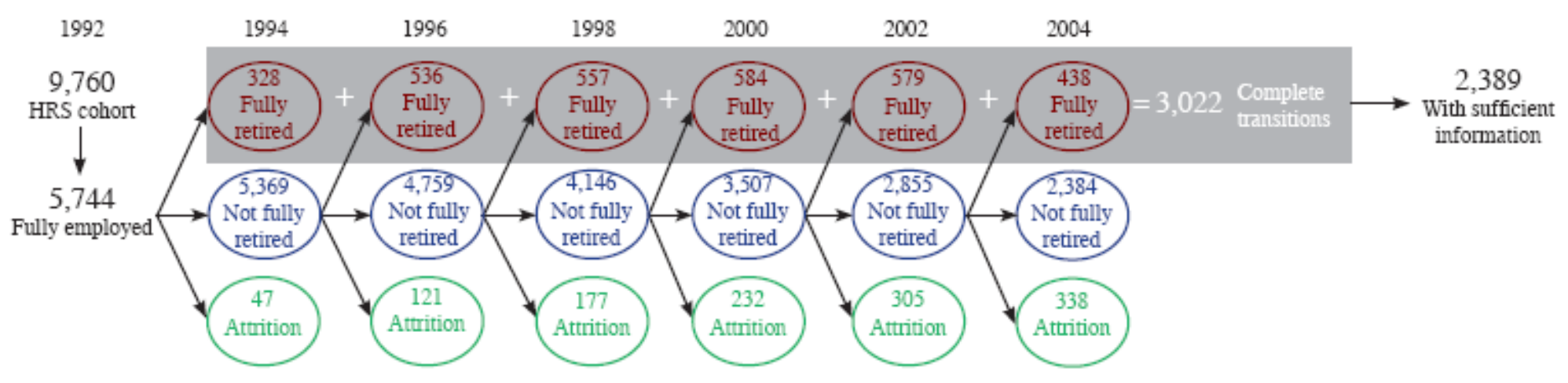

Notes: Fully employed $=$ at least 30 hours usually worked per week and self-reported as "not retired."

Fully retired $=0$ hours usually worked per week and self-reported as "completely retired."

Source: Authors' calculations using data from the Health and Retirement Study (HRS), 1992-2004, and the RAND version G database. 


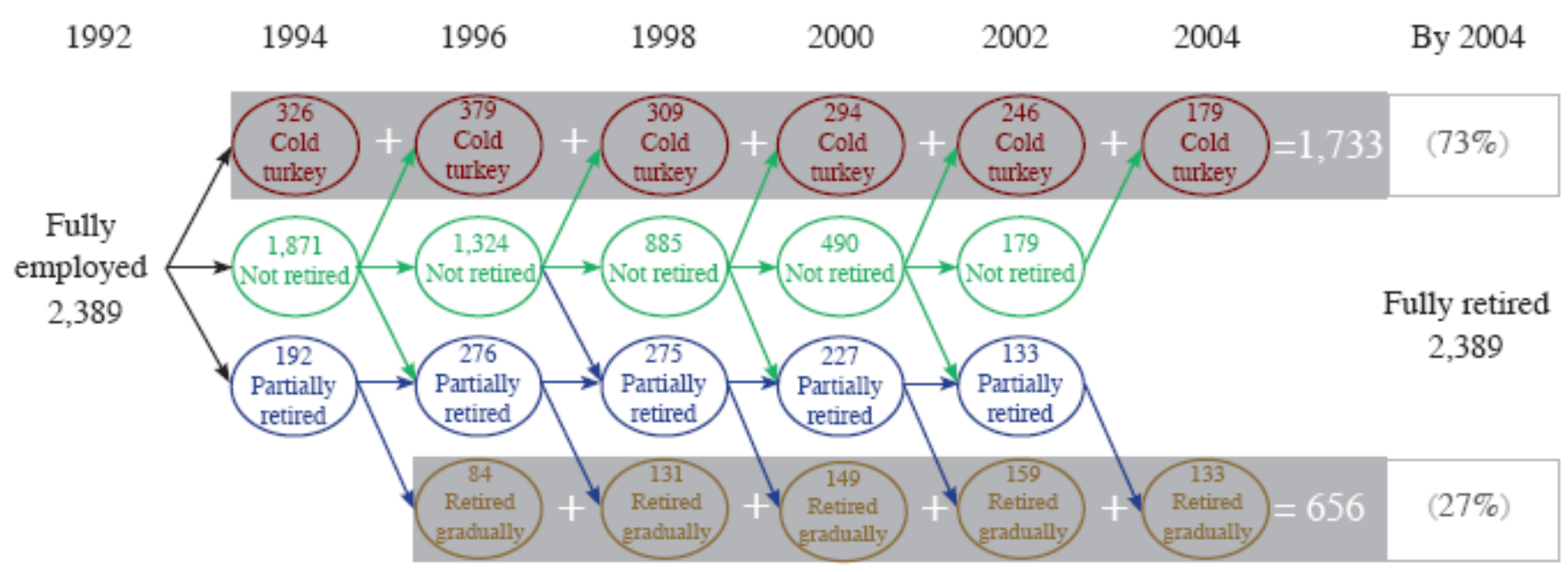

Notes: Fully employed $=$ At least 30 hours usually worked per week and self-reported as "not retired." Fully retired $\quad=0$ hours usually worked per week and self-reported as "completely retired."

Cold turkey = Fully Retired Cold Turkey

Not retired = Self-reported as "not retired."

Partially retired = Self-reported as "partly retired" prior to self-reported as "completely retired."

Retired gradually $=$ Fully retired after gradual retirement.

Source: Authors' calculations using data from the Health and Retirement Study (HRS), 1992-2004, and the RAND version G database. 
Appendices 


\section{Appendix A. Formal Definition of the Concept of Happiness}

What is happiness?

We experience different kind of feelings. Some of these are enjoyable feelings. For example, one can enjoy life. Others feelings are unpleasant, such as sadness. Happiness is defined here as the degree to which a variety of feelings that a person experiences are pleasant or enjoyable in character.

This specific definition of happiness focuses on: (1) more or less stable feelings as opposed to temporary feelings, such as the sensory delight of a chocolate; (2) an evaluation of one's feelings in general as opposed to the evaluation of a specific domain of life, such as satisfaction with job; (3) an affective as opposed to a cognitive notion of happiness, such as the degree to which we think we have achieved our goals.

What is not happiness?

As defined here, the word happiness cannot be used in an ambiguous way, as synonymous with quality of life, subjective well-being, retirement satisfaction, positive mood and contentment (for a discussion of these concepts, refer to: Diener 2000; Gilbert 2007; Layard 2005; Rehberg 2000; Veenhoven 1991; Veenhoven 2006). 'Quality of life' is a broader concept, including other attributes of life such as material affluence, security and other conditions for a good life. Here, we are only interested in quality of life as perceived by the individual.

'Subjective well-being' is also a broader concept than happiness, as it includes passing pleasures, such as the sensory delight of a chocolate, or satisfaction with specific domains of life, such as satisfaction with marriage, job, and the neighborhood. Here we are only interested in a stable and generalized feeling of subjective well-being.

'Retirement satisfaction' involves more or less enduring feelings. However, this is an evaluation about a specific domain in life and not a general evaluation about one's feelings. Retirement satisfaction is also a more of a cognitive construct, and thus more vulnerable to social comparison than our measure of happiness, which rely to a greater extent on unreasoned feelings. Although retirement satisfaction and happiness can be highly correlated, they are not the same. For example, people can be satisfied with retirement because of the leisure time gained, but still feel lonely. Also, people can be 
dissatisfied with retirement because of small retirement income, but nevertheless feel happy in general.

Finally, our definition of happiness also differentiates from moods, emotions, and contentment. Judgments about 'moods and emotions' draw heavily on unreasoned affects, but are only temporary reactions to events, and therefore less stable across time. 'Contentment' involves a more cognitively-guided evaluation about the degree to which aspirations are met.

\section{Appendix B. Latent “Affect”}

We use five dichotomous variables in the HRS (recording feelings of happiness, enjoyment of life, loneliness, depression, and sadness) as our basic measures of "Happiness." Respondents who said they were happy when fully employed or fully retired also tended to say that they enjoyed life and were not lonely, depressed, nor sad. This common variance suggests that the five variables in the HRS are indicators a single latent variable, which we call "Affect." We identify this latent variable to extend the range of scores available in our dependent variable. This is particularly important given the censoring problem we face when using the dichotomous HRS variables separately.

We construct the value "Affect" at the last wave of full employment ("Affect $t_{t 1}$ ") and at the first wave of full retirement ("Affect ${ }_{\mathrm{t2}}$ ") using Confirmatory Factor Analysis (CFA). At each time point the value of "Affect" is a function of four components: (1) the five observed HRS indicator variables (happy, enjoy, lonely, depressed and sad), (2) weighted with a given factor loading constrained to be equal across time, and (3) an error term for each observed indicator variable that is (4) allowed to covary with itself across time (i.e. autocorrelated measurement errors) to control for the effects of retest (e.g. memory), and (5) a covariance between "Affect $t_{t}$ " and"Affect $t_{t 2}$ ". The dependent "Affect" variable used in the regression model is the change in the value of the latent "Affect" variable at the two time points ("Affect $t_{11}$ - "Affect $t_{22}$ ").

Appendix Table 1 shows that the latent variables "Affect $t_{11}$ " and"Affect $t_{2}$ " accounted for a high amount of variance (R2) for feelings of sadness $(0.80,0.85)$, depression $(0.79,0.84)$, happiness $(0.77,0.83)$, enjoyment of life $(0.74,0.79)$, and a moderate amount for loneliness $(0.63,0.67)$. These results suggest that the indicators 
used tend to hold together and are consistent with the assumption that the indicators represent one underlying latent variable. Residuals tell the same story highlighting all of the variance other than the construct happiness underlying the "Affect" variables.

Another way to check that the estimated "Affect" variables are consistent with the assumption that the indicators represent one underlying latent variable is to look at the correlations between these variables. As illustrated in Appendix Table 2, the correlations between the "Affect" variables and the indicator variables at each time point are high (in absolute value terms). Across time points, the correlations are not as high.

The model also showed acceptable global model fit $(\mathrm{df}=33$; Minimum Fit Function Chi-Square $=145.08, \mathrm{p}<.001$; Root Mean Square Error of Approximation [RMSEA $=0.038 ; 90$ Percent Confidence Interval for RMSEA $=0.032 ; 0.044 ; \mathrm{P}-$ Value for Test of Close Fit [RMSEA < 0.05] = 1.00; Comparative Fit Index [CFI] = 0.98; Standardized Root Mean Square Residual [SRMR] = 0.11; Goodness of Fit Index [GFI] = 1.00; Adjusted Goodness of Fit Index [AGFI] = 0.99; Parsimony Goodness of Fit Index $[$ PGFI $]=0.60$ ). Because the chi-square statistic is widely recognized to be sensitive to sample size and non-normality (Albright 2006), we rely on alternative fit statistics.

Since dichotomous variables do not have units of measurement and are nonnormal, we used PRELIS (Jöreskog and Sörbom 1996b) to estimate a polychoric correlation and asymptotic covariance matrices, and then used the matrices in LISREL (Jöreskog and Sörbom 1996a) to estimate the one factor measurement model with Weighted Least Squares (WLS) (Albright 2006; Jöreskog 2005[2002]).

\section{Appendix C. Data Appendix}

Missing Values

Missing values in the variables used for the selection of the sample were handled by deriving the information from other variables whenever it was possible. In addition, we performed a single imputation on hours usually worked per week and self-reported retirement status.

After selecting the relevant sample, the remaining missing values were handled by using the Multiple Imputation by Chained Equations (MICE). The analyses were conducted on five iterations of this imputation. This method is one of 
the best available techniques to deal with non-response (Allison 2001; Royston 2004). The advantages of MICE include: (1)it reduces the loss of information in panel data; (2)it prevents underestimating the standard errors by doing the imputation more than once, each time including a random component in the imputation; and (3) it is suited to the type of missing data in our dataset, which appear missing at random (MAR) according to statistical tests, meaning that other variables in the dataset can partly explain them.

\section{Explanatory Variables}

Demographics. Included in the regressions are the gender, race/ethnicity, difference in age, and education of respondents. Respondents are classified as: (1) white and non-hispanic, or (2) non-white and/or hispanic. The difference in ages of the individual in the last wave of full employment and at the first wave of full retirement is included. Respondents are categorized as attaining education of high school or less or more than high school.

Log of mean wealth. This variable is the natural logarithm of the mean of nonhousing wealth from the first wave to the wave an individual is coded as fully retired. The variable is recoded to zero if mean wealth is zero or negative. The values in each wave were adjusted by Consumer Price Index (CPI) to 2003 real dollars.

Occupation. Blue-collar workers are respondents who classified themselves in any of the following occupational categories: (1) farming, forestry, or fishing; (2) mechanics or repair; (3) precision production; (4) operators (machine, transportation, or handlers); and (5) armed forces.

Unemployment. This variable controls for a possible misclassification of an individual as retired when he/she is actually unemployed. If the labor force status is unemployed in the wave an individual is coded as fully retired, this variable takes a value of one. 
Appendix Table 1. Measurement Model for the Latent Affect Variable $(\mathrm{N}=2,389)$

\begin{tabular}{lccccccc}
\hline \hline Indicators & Weights & $\begin{array}{c}\text { Standard } \\
\text { Errors }\end{array}$ & & \multicolumn{2}{c}{ Multiple R-Squared } & & \multicolumn{2}{c}{ Residual } \\
Happiness & 1.00 & - & 0.77 & 0.83 & & 0.23 & 0.17 \\
Enjoyment of life & 0.98 & 0.02 & 0.74 & 0.79 & 0.26 & 0.21 \\
Loneliness & -0.90 & 0.02 & 0.63 & 0.67 & & 0.37 & 0.33 \\
Sadness & -1.01 & 0.02 & 0.80 & 0.85 & & 0.20 & 0.15 \\
Depression & -1.01 & 0.02 & 0.79 & 0.84 & & 0.21 & 0.16
\end{tabular}

Note: Weight for item happiness was fixed at 1. All weights were constrained to be invariant across time, and are significant at $\mathrm{p}<.001$. 
Appendix Table 2. Correlations Between Latent Affect and Indicator Variables $(\mathrm{N}=2,389)$

\begin{tabular}{|c|c|c|c|c|c|c|c|c|c|c|c|c|}
\hline & Affects $_{\mathrm{t} 1}$ & Affects $_{\mathrm{t} 2}$ & Happy $_{t 1}$ & Happy $_{\mathrm{t} 2}$ & Enjoy $_{1}$ & Enjoy $_{2}$ & Lonely $_{\mathrm{t} 1}$ & Lonely $_{\mathrm{t} 2}$ & Depres.t1 $_{\text {t1 }}$ & Depres.t2 & $\operatorname{Sad}_{t 1}$ & $\mathrm{Sad}_{\mathrm{t} 2}$ \\
\hline Affects $_{\mathrm{t} 1}$ & 1.000 & & & & & & & & & & & \\
\hline Affects $_{\mathrm{t} 2}$ & 0.535 & 1.000 & & & & & & & & & & \\
\hline Happy $_{t 1}$ & 0.725 & 0.382 & 1.000 & & & & & & & & & \\
\hline Happyt2 & 0.409 & 0.763 & 0.462 & 1.000 & & & & & & & & \\
\hline Enjoy $_{\text {t1 }}$ & 0.637 & 0.306 & 0.801 & 0.431 & 1.000 & & & & & & & \\
\hline Enjoyt $_{\mathrm{t} 2}$ & 0.277 & 0.655 & 0.415 & 0.817 & 0.522 & 1.000 & & & & & & \\
\hline Lonely $_{\mathrm{t} 1}$ & -0.607 & -0.348 & -0.517 & -0.326 & -0.503 & -0.295 & 1.000 & & & & & \\
\hline Lonely $_{\mathrm{t} 2}$ & -0.386 & -0.665 & -0.378 & -0.660 & -0.376 & -0.613 & 0.565 & 1.000 & & & & \\
\hline Depres.t1 $_{\text {.t }}$ & -0.772 & -0.383 & -0.636 & -0.371 & -0.522 & -0.271 & 0.670 & 0.438 & 1.000 & & & \\
\hline Depres.t2 & -0.453 & -0.823 & -0.436 & -0.775 & -0.385 & -0.632 & 0.443 & 0.727 & 0.511 & 1.000 & & \\
\hline $\operatorname{Sad}_{t 1}$ & -0.776 & -0.385 & -0.577 & -0.347 & -0.543 & -0.241 & 0.698 & 0.422 & 0.794 & 0.441 & 1.000 & \\
\hline $\mathrm{Sad}_{\mathrm{t} 2}$ & -0.463 & -0.841 & -0.369 & -0.721 & -0.359 & -0.682 & 0.447 & 0.763 & 0.446 & 0.819 & 0.455 & 1.000 \\
\hline
\end{tabular}

Notes: $G$ iven the that all indicator variables are dichotomous, we report tetrachoric and polychoric correlations.

${ }_{11}=$ last wave of full employment; ${ }_{t_{2}}=$ first wave of full retirement. 
Appendix Table 3. Ordered Logit Results on Five Indicator Variables $(\mathrm{N}=2,389)$

\begin{tabular}{|c|c|c|c|c|c|}
\hline \multicolumn{6}{|c|}{ Enjoy } \\
\hline & Happy & Life & Lonely & Depressed & Sad \\
\hline \multirow[t]{2}{*}{ Cold Turkey Retirement } & 0.086 & 0.262 & -0.058 & 0.236 & -0.101 \\
\hline & $(0.19)$ & $(0.23)$ & $(0.19)$ & $(0.18)$ & $(0.17)$ \\
\hline \multirow[t]{2}{*}{ Retirement Wanted } & $0.481^{\star \star}$ & 0.250 & $-0.633^{\star \star \star}$ & $-0.470 \star \star$ & $-0.443^{\star *}$ \\
\hline & $(0.16)$ & $(0.18)$ & $(0.14)$ & $(0.15)$ & $(0.14)$ \\
\hline \multirow[t]{2}{*}{ Retirement Partly Wanted } & 0.095 & 0.263 & $-0.917^{\star \star \star}$ & -0.150 & -0.262 \\
\hline & $(0.25)$ & $(0.29)$ & $(0.24)$ & $(0.22)$ & $(0.22)$ \\
\hline \multirow[t]{2}{*}{ Spouse Death } & $-1.110^{\star \star}$ & $-1.462^{\star \star \star}$ & $2.493^{\star \star \star}$ & 0.235 & $0.707^{*}$ \\
\hline & $(0.34)$ & $(0.38)$ & $(0.30)$ & $(0.35)$ & $(0.31)$ \\
\hline \multirow[t]{2}{*}{ Improved Health } & $0.262^{\star \star \star}$ & $0.354^{\star \star \star}$ & $-0.160^{\star \star}$ & $-0.282^{\star \star \star}$ & $-0.231^{\star \star *}$ \\
\hline & $(0.06)$ & $(0.07)$ & $(0.06)$ & $(0.05)$ & $(0.05)$ \\
\hline \multirow[t]{2}{*}{ Any DB } & -0.037 & 0.016 & 0.128 & 0.059 & 0.042 \\
\hline & $(0.12)$ & $(0.15)$ & $(0.12)$ & $(0.12)$ & $(0.11)$ \\
\hline \multirow[t]{2}{*}{ Years Between Emp. and Ret. } & 0.061 & $0.114^{*}$ & -0.048 & 0.071 & 0.044 \\
\hline & $(0.05)$ & $(0.06)$ & $(0.05)$ & $(0.04)$ & $(0.04)$ \\
\hline \multirow[t]{2}{*}{ Male } & -0.214 & -0.099 & -0.015 & -0.048 & -0.192 \\
\hline & $(0.12)$ & $(0.15)$ & $(0.13)$ & $(0.12)$ & $(0.12)$ \\
\hline \multirow[t]{2}{*}{ White Non-Hispanic } & -0.004 & 0.124 & -0.067 & -0.087 & -0.002 \\
\hline & $(0.14)$ & $(0.18)$ & $(0.14)$ & $(0.14)$ & $(0.13)$ \\
\hline \multirow[t]{2}{*}{ Log of Mean Wealth } & $-0.045^{\star}$ & 0.041 & -0.010 & -0.021 & -0.013 \\
\hline & $(0.02)$ & $(0.02)$ & $(0.02)$ & $(0.02)$ & $(0.02)$ \\
\hline \multirow[t]{2}{*}{ More than High School } & 0.228 & 0.039 & -0.191 & -0.189 & -0.056 \\
\hline & $(0.13)$ & $(0.16)$ & $(0.13)$ & $(0.13)$ & $(0.12)$ \\
\hline \multirow[t]{2}{*}{ Blue-Collar } & -0.092 & 0.208 & -0.136 & 0.246 & 0.052 \\
\hline & $(0.14)$ & $(0.18)$ & $(0.15)$ & $(0.14)$ & $(0.13)$ \\
\hline \multirow[t]{2}{*}{ Unemployed } & -1.245 & $-1.943^{\star *}$ & 1.048 & 0.517 & 0.935 \\
\hline & $(0.67)$ & $(0.69)$ & $(0.67)$ & $(0.71)$ & $(0.65)$ \\
\hline \multirow[t]{2}{*}{ Constant (cut 1 for ologit) } & $-2.641^{\star \star \star}$ & $-1.976^{\star \star \star}$ & $-3.717^{\star \star \star}$ & $-2.843^{\star \star \star}$ & $-3.041^{* * *}$ \\
\hline & $(0.35)$ & $(0.42)$ & $(0.36)$ & $(0.34)$ & $(0.32)$ \\
\hline \multirow[t]{2}{*}{ Constant (cut 2 for ologit) } & $2.383^{\star \star \star}$ & $4.200 * \star \star$ & $1.517^{\star \star \star}$ & $2.101^{\star \star \star}$ & $1.642^{\star * *}$ \\
\hline & $(0.35)$ & $(0.44)$ & $(0.34)$ & $(0.33)$ & $(0.31)$ \\
\hline Log Likelihood & -1295 & -895 & -1223 & -1334 & -1440 \\
\hline
\end{tabular}

Note: Change from the last wave of full employment to the first wave of full retirement. Regular oredered logit regression coefficients reported for the indicator variables. Standard errors are in parentheses.

${ }^{\star} p<.05 ; * \star p<.01 ; * \star * p<.001$ (two tailed tests for all variables). 
Appendix Table 4. Regression Results on Latent Affect $(\mathrm{N}=2,389)$

\begin{tabular}{|c|c|}
\hline & Latent Affect \\
\hline \multirow[t]{2}{*}{ Cold Turkey Retirement } & 0.002 \\
\hline & $(0.020)$ \\
\hline \multirow[t]{2}{*}{ Retirement Wanted } & $0.056^{\star \star \star}$ \\
\hline & $(0.010)$ \\
\hline \multirow[t]{2}{*}{ Retirement Partly Wanted } & $0.045^{\star}$ \\
\hline & $(0.020)$ \\
\hline \multirow[t]{2}{*}{ Spouse Death } & $-0.157^{\star \star \star}$ \\
\hline & $(0.030)$ \\
\hline \multirow[t]{2}{*}{ Improved Health } & $0.034^{\star \star \star}$ \\
\hline & $(0.000)$ \\
\hline \multirow[t]{2}{*}{ Any DB } & -0.004 \\
\hline & $(0.010)$ \\
\hline \multirow[t]{2}{*}{ Years Between Emp. and Ret. } & 0.001 \\
\hline & $(0.000)$ \\
\hline \multirow[t]{2}{*}{ Male } & -0.001 \\
\hline & $(0.010)$ \\
\hline \multirow[t]{2}{*}{ White Non-Hispanic } & 0.006 \\
\hline & $(0.010)$ \\
\hline \multirow[t]{2}{*}{ Log of Mean Wealth } & 0.001 \\
\hline & $(0.000)$ \\
\hline \multirow[t]{2}{*}{ More than High School } & 0.016 \\
\hline & $(0.010)$ \\
\hline \multirow[t]{2}{*}{ Blue-Collar } & -0.003 \\
\hline & $(0.010)$ \\
\hline \multirow[t]{2}{*}{ Unemployed } & $-0.180^{*}$ \\
\hline & $(0.070)$ \\
\hline \multirow[t]{2}{*}{ Constant } & $-0.070^{\star}$ \\
\hline & $(0.030)$ \\
\hline $\mathrm{R}^{2}$ & 0.0533 \\
\hline
\end{tabular}

Note: Change from the last wave of full employment to the first wave of full retirement. Unstandardized regression coefficients reported for Latent Affect. Standard errors are in parentheses.

${ }^{*} p<.05 ;{ }^{* \star} p<.01 ; * \star * p<.001$ (two tailed tests for all variables). 
Appendix Table 5. Logit Marginal Effects on Five Indicator Variables for Positive Sample

\begin{tabular}{|c|c|c|c|c|c|}
\hline & $\begin{array}{c}\text { Happy } \\
\text { to } \\
\text { Not-Happy }\end{array}$ & $\begin{array}{c}\text { Enjoy Life } \\
\text { to } \\
\text { Not-Enjoy Life }\end{array}$ & $\begin{array}{c}\text { Not-Lonely } \\
\text { to } \\
\text { Lonely } \\
\end{array}$ & $\begin{array}{c}\text { Not-Depressed } \\
\text { to } \\
\text { Depressed } \\
\end{array}$ & $\begin{array}{c}\text { Not-Sad } \\
\text { to } \\
\text { Sad } \\
\end{array}$ \\
\hline Cold Turkey Retirement & $\begin{array}{l}0.010 \\
(0.02)\end{array}$ & $\begin{array}{l}-0.013 \\
(0.01)\end{array}$ & $\begin{array}{l}0.010 \\
(0.02)\end{array}$ & $\begin{array}{l}0.027 \\
(0.02)\end{array}$ & $\begin{array}{c}0.01 \\
(0.02)\end{array}$ \\
\hline Retirement Wanted & $\begin{array}{c}-0.087^{\star \star \star} \\
(0.02)\end{array}$ & $\begin{array}{c}-0.047^{\star \star \star} \\
(0.01)\end{array}$ & $\begin{array}{c}-0.084^{\star \star *} \\
(0.02)\end{array}$ & $\begin{array}{c}-0.087^{\star \star \star} \\
(0.02)\end{array}$ & $\begin{array}{c}-0.086^{\star \star \star} \\
(0.02)\end{array}$ \\
\hline Retirement Partly Wanted & $\begin{array}{l}-0.020 \\
(0.01)\end{array}$ & $\begin{array}{c}-0.024^{\star \star} \\
(0.01)\end{array}$ & $\begin{array}{c}-0.046^{\star *} \\
(0.02)\end{array}$ & $\begin{array}{r}-0.022 \\
(0.02)\end{array}$ & $\begin{array}{l}-0.030 \\
(0.02)\end{array}$ \\
\hline Spouse Death & $\begin{array}{l}0.135^{\star} \\
(0.06)\end{array}$ & $\begin{array}{l}0.125^{\star} \\
(0.05)\end{array}$ & $\begin{array}{c}0.478^{\star \star \star} \\
(0.08)\end{array}$ & $\begin{array}{l}0.046 \\
(0.04)\end{array}$ & $\begin{array}{l}0.117^{*} \\
(0.06)\end{array}$ \\
\hline Improved Health & $\begin{array}{c}-0.017^{\star \star \star} \\
(0.00)\end{array}$ & $\begin{array}{c}-0.014^{\star \star \star} \\
(0.00)\end{array}$ & $\begin{array}{l}-0.010 \\
(0.01)\end{array}$ & $\begin{array}{c}-0.024^{\star \star \star} \\
(0.01)\end{array}$ & $\begin{array}{c}-0.025^{\star \star \star} \\
(0.01)\end{array}$ \\
\hline Any DB & $\begin{array}{l}0.028^{\star} \\
(0.01)\end{array}$ & $\begin{array}{l}0.012 \\
(0.01)\end{array}$ & $\begin{array}{l}0.004 \\
(0.01)\end{array}$ & $\begin{array}{l}0.013 \\
(0.01)\end{array}$ & $\begin{array}{l}0.019 \\
(0.01)\end{array}$ \\
\hline Years Between Emp. and Ret. & $\begin{array}{l}0.002 \\
(0.00)\end{array}$ & $\begin{array}{l}-0.002 \\
(0.00)\end{array}$ & $\begin{array}{l}-0.004 \\
(0.00)\end{array}$ & $\begin{array}{l}0.007 \\
(0.00)\end{array}$ & $\begin{array}{l}0.006 \\
(0.01)\end{array}$ \\
\hline Male & $\begin{array}{l}-0.007 \\
(0.01)\end{array}$ & $\begin{array}{l}-0.007 \\
(0.01)\end{array}$ & $\begin{array}{l}-0.016 \\
(0.01)\end{array}$ & $\begin{array}{c}-0.031^{*} \\
(0.01)\end{array}$ & $\begin{array}{c}-0.061^{\star \star \star} \\
(0.02)\end{array}$ \\
\hline White Non-Hispanic & $\begin{array}{l}-0.014 \\
(0.01)\end{array}$ & $\begin{array}{l}-0.013 \\
(0.01)\end{array}$ & $\begin{array}{c}-0.033^{\star} \\
(0.02)\end{array}$ & $\begin{array}{c}-0.051^{\star \star} \\
(0.02)\end{array}$ & $\begin{array}{l}-0.028 \\
(0.02)\end{array}$ \\
\hline Log of Mean Wealth & $\begin{array}{l}-0.003 \\
(0.00)\end{array}$ & $\begin{array}{c}-0.003^{\star \star} \\
(0.00)\end{array}$ & $\begin{array}{c}-0.006^{\star \star} \\
(0.00)\end{array}$ & $\begin{array}{c}-0.005^{\star} \\
(0.00)\end{array}$ & $\begin{array}{c}-0.008^{\star * *} \\
(0.00)\end{array}$ \\
\hline More than High School & $\begin{array}{c}-0.036^{\star *} \\
(0.01)\end{array}$ & $\begin{array}{l}-0.006 \\
(0.01)\end{array}$ & $\begin{array}{c}-0.029 * \\
(0.01)\end{array}$ & $\begin{array}{c}-0.063^{\star \star \star} \\
(0.01)\end{array}$ & $\begin{array}{c}-0.035^{\star} \\
(0.02)\end{array}$ \\
\hline Blue-Collar & $\begin{array}{l}0.001 \\
(0.01)\end{array}$ & $\begin{array}{l}-0.009 \\
(0.01)\end{array}$ & $\begin{array}{l}0.008 \\
(0.02)\end{array}$ & $\begin{array}{l}0.019 \\
(0.02)\end{array}$ & $\begin{array}{l}0.013 \\
(0.02)\end{array}$ \\
\hline Unemployed & $\begin{array}{l}0.126 \\
(0.11)\end{array}$ & $\begin{array}{l}0.118 \\
(0.09)\end{array}$ & $\begin{array}{l}0.116 \\
(0.12)\end{array}$ & $\begin{array}{l}0.031 \\
(0.09)\end{array}$ & $\begin{array}{l}0.141 \\
(0.14)\end{array}$ \\
\hline Log Likelihood & -665 & -679 & -775 & -679 & -775 \\
\hline $\mathrm{N}$ & 2089 & 2221 & 2134 & 2106 & 2099 \\
\hline
\end{tabular}

Note: The "positive sample" includes only individuals starting with positive affects at the last wave of full employment. The marginal effects are reported, reflecting the probability of a negative change in each indicator variable (as opossed to no change) from the last wave of full employment to the first wave of full retirement, with all variables held at their means. Standard errors are in parentheses.

${ }^{*} p<.05 ;{ }^{* \star} p<.01 ;{ }^{* \star *} p<.001$ (two tailed tests for all variables). 
Appendix Table 6. Logit Marginal Effects on Five Indicator Variables for Negative Sample

\begin{tabular}{|c|c|c|c|c|c|}
\hline & $\begin{array}{c}\text { Not-Happy } \\
\text { to } \\
\text { Happy } \\
\end{array}$ & $\begin{array}{c}\text { Not-Enjoy Life } \\
\text { to } \\
\text { Enjoy Life } \\
\end{array}$ & $\begin{array}{c}\text { Lonely } \\
\text { to } \\
\text { Not-Lonely } \\
\end{array}$ & $\begin{array}{c}\text { Depressed } \\
\text { to } \\
\text { Not-Depressed }\end{array}$ & $\begin{array}{c}\text { Sad } \\
\text { to } \\
\text { Not-Sad }\end{array}$ \\
\hline Cold Turkey Retirement & $\begin{array}{l}0.009 \\
(0.09)\end{array}$ & $\begin{array}{l}0.090 \\
(0.11)\end{array}$ & $\begin{array}{l}0.191 \\
(0.12)\end{array}$ & $\begin{array}{l}-0.034 \\
(0.11)\end{array}$ & $\begin{array}{l}0.098 \\
(0.13)\end{array}$ \\
\hline Retirement Wanted & $\begin{array}{c}0.227^{\star \star \star} \\
(0.06)\end{array}$ & $\begin{array}{c}0.258^{\star \star *} \\
(0.08)\end{array}$ & $\begin{array}{l}0.160 \\
(0.08)\end{array}$ & $\begin{array}{c}0.262^{\star \star \star} \\
(0.07)\end{array}$ & $\begin{array}{c}0.240^{\star * *} \\
(0.07)\end{array}$ \\
\hline Retirement Partly Wanted & $\begin{array}{l}0.115 \\
(0.09)\end{array}$ & $\begin{array}{l}0.047 \\
(0.12)\end{array}$ & $\begin{array}{l}0.284^{*} \\
(0.11)\end{array}$ & $\begin{array}{l}0.201^{*} \\
(0.10)\end{array}$ & $\begin{array}{l}0.225^{\star} \\
(0.09)\end{array}$ \\
\hline Spouse Death & $\begin{array}{l}-0.242 \\
(0.19)\end{array}$ & $\begin{array}{l}-0.350 \\
(0.23)\end{array}$ & $\begin{array}{l}0.055 \\
(0.24)\end{array}$ & $\begin{array}{l}0.109 \\
(0.17)\end{array}$ & $\begin{array}{l}-0.286 \\
(0.17)\end{array}$ \\
\hline Improved Health & $\begin{array}{l}0.041 \\
(0.03)\end{array}$ & $\begin{array}{l}0.032 \\
(0.03)\end{array}$ & $\begin{array}{l}0.086^{*} \\
(0.04)\end{array}$ & $\begin{array}{l}0.049 \\
(0.03)\end{array}$ & $\begin{array}{l}0.028 \\
(0.03)\end{array}$ \\
\hline Any DB & $\begin{array}{l}-0.044 \\
(0.06)\end{array}$ & $\begin{array}{l}0.118 \\
(0.08)\end{array}$ & $\begin{array}{l}0.039 \\
(0.07)\end{array}$ & $\begin{array}{l}0.059 \\
(0.07)\end{array}$ & $\begin{array}{l}0.092 \\
(0.07)\end{array}$ \\
\hline Years Between Emp. and Ret. & $\begin{array}{r}-0.002 \\
(0.02)\end{array}$ & $\begin{array}{l}0.028 \\
(0.02)\end{array}$ & $\begin{array}{l}0.058 \\
(0.03)\end{array}$ & $\begin{array}{l}-0.008 \\
(0.03)\end{array}$ & $\begin{array}{l}0.050 \\
(0.03)\end{array}$ \\
\hline Male & $\begin{array}{r}-0.023 \\
(0.06)\end{array}$ & $\begin{array}{l}-0.023 \\
(0.08)\end{array}$ & $\begin{array}{l}0.134 \\
(0.08)\end{array}$ & $\begin{array}{l}0.098 \\
(0.07)\end{array}$ & $\begin{array}{c}0.195^{\star \star} \\
(0.07)\end{array}$ \\
\hline White Non-Hispanic & $\begin{array}{r}-0.030 \\
(0.06)\end{array}$ & $\begin{array}{l}0.105 \\
(0.09)\end{array}$ & $\begin{array}{l}-0.008 \\
(0.08)\end{array}$ & $\begin{array}{l}0.011 \\
(0.07)\end{array}$ & $\begin{array}{l}-0.093 \\
(0.07)\end{array}$ \\
\hline Log of Mean Wealth & $\begin{array}{c}0.015^{\star} \\
(0.01)\end{array}$ & $\begin{array}{l}0.009 \\
(0.01)\end{array}$ & $\begin{array}{l}0.010 \\
(0.01)\end{array}$ & $\begin{array}{c}0.038^{\star * *} \\
(0.01)\end{array}$ & $\begin{array}{l}0.016 \\
(0.01)\end{array}$ \\
\hline More than High School & $\begin{array}{l}0.033 \\
(0.07)\end{array}$ & $\begin{array}{l}0.018 \\
(0.09)\end{array}$ & $\begin{array}{l}0.030 \\
(0.08)\end{array}$ & $\begin{array}{l}0.092 \\
(0.08)\end{array}$ & $\begin{array}{l}-0.123 \\
(0.08)\end{array}$ \\
\hline Blue-Collar & $\begin{array}{l}-0.007 \\
(0.07)\end{array}$ & $\begin{array}{l}0.113 \\
(0.08)\end{array}$ & $\begin{array}{l}-0.156 \\
(0.09)\end{array}$ & $\begin{array}{l}-0.120 \\
(0.08)\end{array}$ & $\begin{array}{l}-0.104 \\
(0.08)\end{array}$ \\
\hline Unemployed & $\begin{array}{l}- \\
-\end{array}$ & $\begin{array}{l}- \\
-\end{array}$ & - & - & - \\
\hline Log Likelihood & -171 & -84 & -159 & -161 & -175 \\
\hline $\mathrm{N}$ & 300 & 168 & 255 & 283 & 290 \\
\hline
\end{tabular}

Note: The "negative sample" includes only individuals starting with negative affects at the last wave of full employment. The marginal effects are reported, reflecting the likelihood of a positive change in each indicator variable (as opossed to no change) from the last wave of full employment to the first wave of full retirement, with all variables held at their means. Standard errors are in parentheses.

${ }^{*} p<.05 ;{ }^{* *} p<.01 ;{ }^{* \star} p<.001$ (two tailed tests for all variables). 


\section{RECENT WORKING PAPERS FROM THE}

\section{CENTER FOR RETIREMENT RESEARCH AT BOSTON COLLEGE}

Why Do Married Men Claim Social Security Benefits So Early? Ignorance, Caddishness, or Something Else?

Steven A. Sass, Wei Sun, and Anthony Webb, October 2007

Measurement Error in Earnings Data in the Health and Retirement Study

Jesse Bricker and Gary V. Engelhardt, October 2007

Evaluating the Advanced Life Deferred Annuity - An Annuity People Might Actually Buy

Guan Gong and Anthony Webb, September 2007

Population Aging, Labor Demand, and the Structure of Wages

Margarita Sapozhnikov and Robert K. Triest, September 2007

Work at Older Ages: Is Raising the Early Retirement Age an Option for Social Security Reform?

John A. Turner, August 2007

The Labor Supply of Older Americans

Alicia H. Munnell and Steven A. Sass, May 2007

Why Do Japanese Workers Remain in the Labor Force So Long?

John B. Williamson and Masa Higo, May 2007

Literacy, Trust and the 401(k) Savings Behavior

Julie R. Agnew, Lisa Szykman, Stephen P. Utkus, and Jean A. Young, May 2007

The Recent Evolution of Pension Funds in the Netherlands: the Trend to Hybrid DB-DC Plans and Beyond

Eduard H.M. Ponds and Bart van Riel, May 2007

Demographic Influences on Saving-Investment Balances in Developing and Developed Economies

Ralph C. Bryant, May 2007

Social Security Spouse and Survivor Benefits for the Modern Family Melissa M. Favreault and C. Eugene Steuerle, February 2007 